Check for updates

Cite this: RSC Adv., 2018, 8, 28895

\title{
Mixed valency in ligand-bridged diruthenium frameworks: divergences and perspectives
}

\begin{abstract}
Arijit Singha Hazari, ${ }^{a}$ Arindam Indra*b and Goutam Kumar Lahiri (DD *a
The present review article illustrates the mixed valence aspects of ligand-bridged symmetric and unsymmetric diruthenium complexes beyond the textbook example of the Creutz-Taube ion as well as the Robin and Day classification by citing representative examples based on our recent observations. The consideration of varied coordination situations involving bridging and ancillary ligands of diverse electronic and steric demands extended important fundamental events including (i) the influence of ancillary ligands besides the bridge in the intermetallic coupling process, (ii) varying profile of the intervalence charge transfer (IVCT) transition in $R u^{I I I} R u^{I \prime}\left(d^{5} d^{6}\right)$ and $R u^{I I I} R u^{I V}$ $\left(d^{5} d^{4}\right)$ mixed valence set up, (iii) divergence between the electrochemical $\left(K_{c}=\right.$ comproportionation constant) and electronic (IVCT) coupling and (iv) occurrence of the hybrid class II-class III situation. Furthermore, additional challenges due to the introduction of redox non-innocent ligands in assigning valence and spin distributions at the metal-ligand interface as well as in differentiating the emerging alternatives of the radical-derived state and the mixed valence situation along the redox chain have been addressed.
\end{abstract}

Received 14th April 2018

Accepted 1st August 2018

DOI: $10.1039 / \mathrm{c} 8 \mathrm{ra03206h}$

rsc.li/rsc-advances cases, the bridge can mediate intermetallic electron transfer from the reduced metal ion to the oxidized one. ${ }^{\mathbf{1}}$ The electron transfer at the mixed valence state is guided by various intriguing factors such as molecular conformation, separation of the redox centers, nature of the spacer and their redox potentials. $^{2}$

In biological systems, the occurrence of polynuclear structures with metal ions in different oxidation states can be found in the oxygen evolving center (OEC) of photosystem II (PSII), ${ }^{3}$ cytochrome-c-oxidase, ${ }^{4}$ ferredoxins, ${ }^{5}$ etc. In PS II, four electrons and four protons are transferred through multistep processes involving high-energy intermediates. The proton-coupled

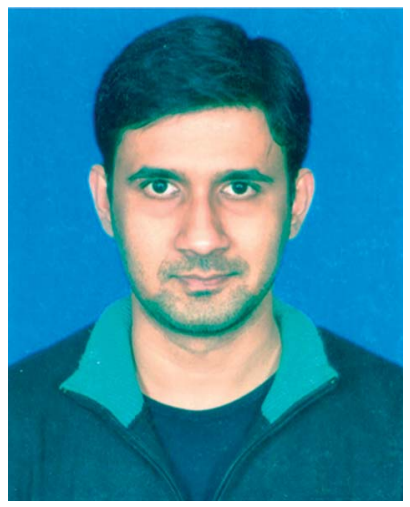

Arijit Singha Hazari received his B.Sc. degree from University of Calcutta and M.Sc. degree from Birla institute of technology and Science. He then joined IIT Bombay in 2013 to pursue his Ph.D. degree under the supervision of Prof. G. K. Lahiri. His research work primarily focusses on the electronic structural aspects of transition metal complexes involving redoxactive ligands and their applications in homogeneous catalysis.

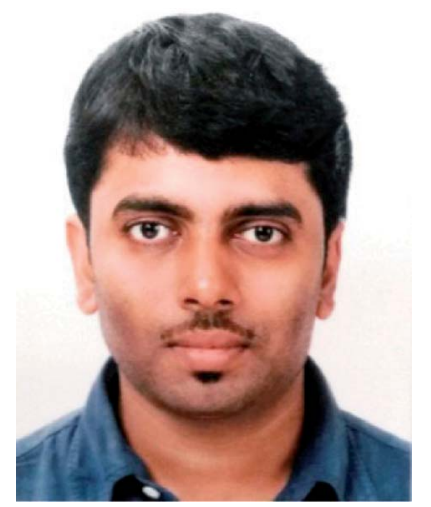

Dr. Arindam Indra received his Ph.D. from IIT Bombay (India) in solid supported catalysis. After completing his postdoctoral research from Technische Universitat Berlin (Germany) and Hanyang University (Korea), he joined IIT (BHU), Varanasi (India) as an assistant professor. His group designs metal organic framework (MOF)-derived functional materials for energy conversion and storage. 


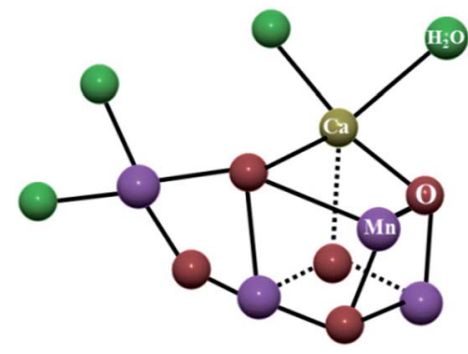

Fig. 1 Oxygen evolving center (OEC) in photosystem II represents oxide-bridged mixed valent $\mathrm{Mn}^{\mathrm{III}}$ and $\mathrm{Mn}^{\mathrm{IV}}$ ions. Reprinted from ref. 6 with the permission of Wiley $\mathrm{VCH}$.

$$
\begin{aligned}
& \left(\mathrm{H}_{3} \mathrm{~N}\right)_{5} \mathrm{Ru}^{\mathrm{II}}-\mathrm{N}^{\prime \prime} \mathrm{N}-\mathrm{Ru}\left(\mathrm{NI}\left(\mathrm{NH}_{3}\right)_{5} 7^{5^{+}}\right. \\
& \left(\mathrm{H}_{3} \mathrm{~N}\right)_{5} \mathrm{Ru}{ }^{l l+0.5}-N^{\prime \prime} \mathrm{N}-\mathrm{Ru}^{\mathrm{ll}+0.5}\left(\mathrm{NH}_{3}\right)_{5} 7^{5^{+}}
\end{aligned}
$$

Fig. 2 Alternate electronic forms of the Creutz-Taube ion.

electron transfer to produce molecular oxygen from water is eased by the mixed valent $\mathrm{Mn}^{\mathrm{III}}-\mathrm{Mn}^{\mathrm{IV}}$ cluster in OEC (Fig. 1$){ }^{6}$ Similarly, dioxygen activation is attained by mixed valent $\mathrm{Cu}^{\mathrm{I}} /$ $\mathrm{Cu}^{\mathrm{II}}$ centers in cytochrome-c-oxidase. ${ }^{7}$

Naturally occurring metal oxides (Spinels $\left(\mathrm{A}^{\mathrm{II}} \mathrm{B}^{\mathrm{III}}{ }_{2} \mathrm{O}_{4}\right)$ ) such as $\mathrm{Fe}_{3} \mathrm{O}_{4}$ (magnetite), ${ }^{8} \mathrm{Co}_{3} \mathrm{O}_{4}, \mathrm{Mn}_{3} \mathrm{O}_{4}$ (ref. 9) and cyanide-bridged Prussian blue $\left(\mathrm{Fe}^{\mathrm{III}}{ }_{4}\left[\mathrm{Fe}^{\mathrm{II}}(\mathrm{CN})_{6}\right]_{3} \cdot 14 \mathrm{H}_{2} \mathrm{O}\right.$, coordination polymer $)$ or its analogues (PBA) also contain metal ions in different oxidation states. ${ }^{10}$

The mixed valency in the designed molecular framework was first described by Creutz and Taube ${ }^{11}$ in the pyrazine-bridged diruthenium complex $\left[\left(\mathrm{NH}_{3}\right)_{5} \mathrm{Ru}(\mu \text {-pyrazine }) \mathrm{Ru}\left(\mathrm{NH}_{3}\right)_{5}\right]^{5+}$ (Fig. 2).

Similarly, Cowan's group ${ }^{12}$ described the mixed valency in biferrocene (A) and biferrocenylene (B). Later, they introduced the tetrathiafulvalene radical cation (C in Fig. 3) as an oddelectron organic compound to show the mixed valency in an organic set up. ${ }^{13}$

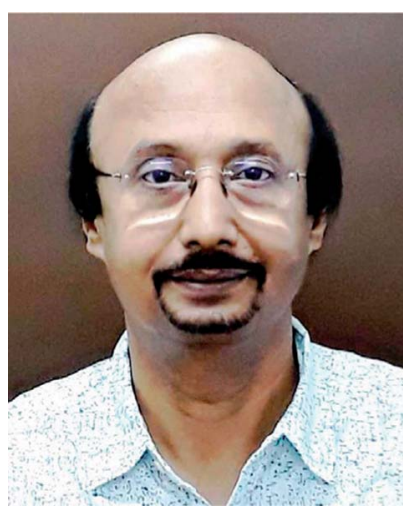

Prof. Goutam Kumar Lahiri received his Ph.D degree from Jadavpur University (IACS) in 1990 under the supervision of Prof. Animesh Chakravorty. After completing his postdoctoral studies at West Virginia University, USA, he joined the department of chemistry at IIT Bombay in 1993, where he is currently an Institute Chair Professor. The main theme of his research is centered around the electron transfer aspects and catalytic features of transition metal complexes.

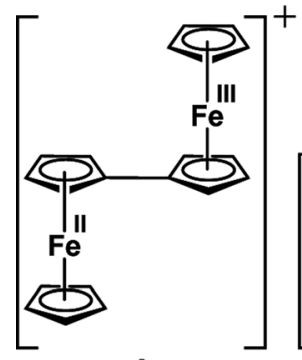

A

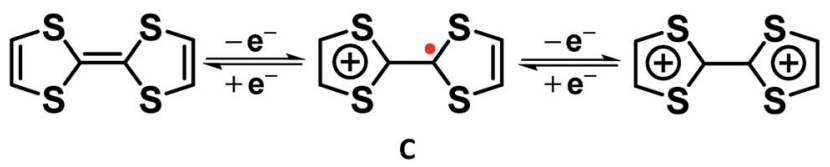

Fig. 3 Electron transfer series of tetrathiafulvalene.

Under the purview of the broader context of mixed valency, diruthenium complexes have been extensively investigated to understand the bridge-mediated electron transfer in mixed valent $\mathrm{Ru}^{\mathrm{II}}\left(\mathrm{d}^{6}\right) \mathrm{Ru}^{\mathrm{III}}\left(\mathrm{d}^{5}\right)$ systems primarily due to better kinetic stability of varying $(+2,+3$ or even +4$)$ oxidation states of the ruthenium ion. ${ }^{14}$

Mixed valence complexes were initially synthesized to understand the fundamental aspects of intermetallic electronic coupling processes. ${ }^{15}$ Later, the focus was also directed towards exploring potential applications of the mixed valence compounds in molecular electronics, molecular wires and quantum automata. ${ }^{16}$ In nanochemistry, the intramolecular electron transfer can be employed to demonstrate the nanojunction device of bulk metal-single molecule-bulk metal. ${ }^{17} \mathrm{~A}$ mixed valence compound that derived molecular switch for long-range electron transfer (15-20 ̊) was also investigated. ${ }^{18}$

\subsection{Classification of mixed valence complexes}

In a ligand-bridged diruthenium(II/III) complex $\left[(\mathrm{AL}) \mathrm{Ru}^{\mathrm{II}}(\mu-\mathrm{BL})\right.$ $\left.\mathrm{Ru}^{\mathrm{III}}(\mathrm{AL})\right](\mathrm{BL}=$ Bridging ligand and $\mathrm{AL}=$ ancillary or peripheral ligand), the electron transfer is initiated from the starting metal center to the arrival site through a bridging ligand (BL). Thus, the bridging ligand plays the role of a mediator to exchange the odd electron between the metal centers at the termini. Hence, the electronic nature and the composition of the bridge play important roles in governing the rate of electron transfer. This provides useful information regarding the separation of the redox potential between the metal centers under chemically identical environments (symmetric set up). In this context, superexchange mechanism provides a better perception about the bridge-mediated intermetallic interaction, which involves efficient overlap of the metal d-orbitals and the $\pi$ orbitals of the spacer (through bond interaction). It can be conceived as a sequential electron transfer between the molecular orbitals of the ligand ( $\pi$ type) and the metal ( $d \pi$ type), resulting in delocalization of the electron density across the 


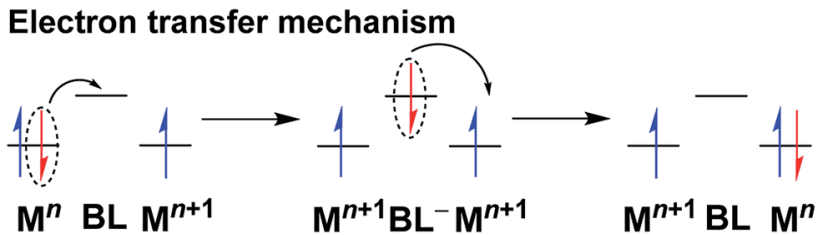

Hole transfer mechanism

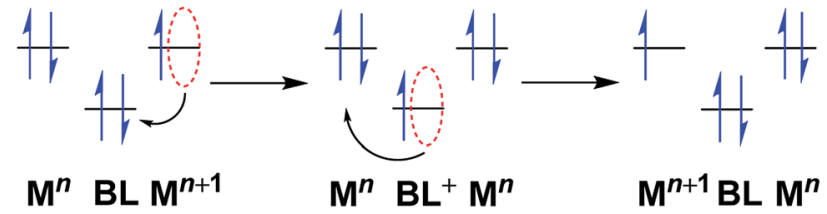

Fig. 4 Bridging ligand-mediated electron transfer and hole transfer pathways in mixed valence complexes. ${ }^{19 c, d}$

metal-bridge-metal domain to some extent, and it occurs via either of the following two pathways (Fig. 4): ${ }^{19}$

Electron transfer pathway. This is operative when the bridging ligand contains low-lying empty $\pi^{*}$-orbitals (LUMO), i.e., $\pi$-acceptor in nature.

Hole transfer pathway. This is followed when the bridging ligand contains high-lying filled $\pi$-orbitals (HOMO), i.e., electron rich in nature.

Robin and Day classified ${ }^{20}$ the mixed valence complexes based on the extent of intermetallic interaction. A very weak to negligible interaction between the metal centers is defined as a class I system, whereas a moderate coupling results in a localized valence-trapped class II ([(AL)R $\left.\left.\mathrm{Ru}^{\mathrm{II}}(\mu-\mathrm{BL}) \mathrm{Ru}^{\mathrm{III}}(\mathrm{AL})\right]\right)$ system. On the other hand, strong intermetallic coupling leads to a valence delocalized $\left[(\mathrm{AL}) \mathrm{Ru}^{2.5}(\mu-\mathrm{BL}) \mathrm{Ru}^{2.5}(\mathrm{AL})\right]$ class III set up. Therefore, detailed studies with varied molecular frameworks have been conducted over the past decades to understand the role of metal ions and ligands (ancillary and bridging) in modulating the intermetallic electronic coupling at the mixed valence state. ${ }^{21}$

\subsection{Comproportionation constant}

Comproportionation constant, $K_{\mathrm{c}}$, implies the thermodynamic stability of the intermediate redox state. For a two-step redox reaction (eqn (1)), the comproportionation constant $\left(K_{\mathrm{c}}\right)$ can be calculated from the potential difference $(\Delta E)$ of the successive redox couples. ${ }^{22}$

$$
\begin{gathered}
{\left[\mathrm{Ru}^{\mathrm{II}}(\mathrm{BL}) \mathrm{Ru}^{\mathrm{II}}\right]^{0}} \\
\text { Reduced form }
\end{gathered} \underset{E_{1}}{\longrightarrow} \begin{aligned}
& {\left[\mathrm{Ru}^{\mathrm{II}}(\mathrm{BL}) \mathrm{Ru}^{\mathrm{III}}\right]^{1+}} \\
& \text { Intermediate form }
\end{aligned} \quad \begin{gathered}
E_{2} \\
{\left[\mathrm{Ru}^{\mathrm{III}}(\mathrm{BL}) \mathrm{Ru}^{\mathrm{III}}\right]^{2+}} \\
\text { Oxidized form }
\end{gathered}
$$

$$
K_{\mathrm{c}}=[\text { intermediate form }]^{2} /\{[\text { reduced form }][\text { oxidized form }]\}
$$

at $298 \mathrm{~K}$,

$$
\Delta G_{\mathrm{c}}=-R T\left(\ln K_{\mathrm{c}}\right)=-n F\left(\Delta E^{0}\right) ;\left(\Delta E=E_{2}-E_{1}\right)
$$

$K_{\mathrm{c}}=10^{\Delta E / 0.059 \mathrm{~V}}, \Delta E$ is the separation between the redox potentials of the successive redox processes.

For a well-defined metal-based redox process, $K_{\mathrm{c}}$ signifies the thermodynamic stability of the mixed valence state. For example, successive $\mathrm{Ru}^{\mathrm{II}} / \mathrm{Ru}^{\mathrm{III}}$ redox couples in the CreutzTaube ion are well separated by $0.39 \mathrm{~V}\left(K_{\mathrm{c}}=10^{6.6}\right)$, leading to a stable mixed valence state with respect to the disproportionation reaction that produces isovalent $\mathrm{Ru}^{\mathrm{II}} / \mathrm{Ru}^{\mathrm{II}}$ and $\mathrm{Ru}^{\mathrm{III}} /$ $\mathrm{Ru}^{\mathrm{III}} \cdot{ }^{11 a, 23}$

According to the Robin and Day classification, a genuine non-interacting class I system is defined by a statistical $K_{\mathrm{c}}$ value of 4 , whereas $K_{\mathrm{c}}$ values close to $10^{5}$ and greater than $10^{6}$ correspond to class II and class III systems, respectively. ${ }^{23}$ In a qualitative sense, $K_{\mathrm{c}}$ values ranging in between the valence localized class II and the valence delocalized class III may represent a borderline class II/III hybrid situation. Despite the Robin and Day classification of the intermetallic interaction based on the value of $K_{\mathrm{c}}$, the equilibrium constant alone cannot provide an evaluation of the metal-metal electronic coupling since the free energy of the comproportionation reaction $\left(\Delta G_{\mathrm{c}}\right)$ consists of several interplaying factors (eqn (2)). ${ }^{24}$

$$
\Delta G_{\mathrm{c}}=\Delta G_{\mathrm{s}}+\Delta G_{\mathrm{e}}+\Delta G_{\mathrm{i}}+\Delta G_{\mathrm{r}}+\Delta G_{\mathrm{af}}+\Delta G_{\mathrm{ip}}
$$

In eqn (2), $\Delta G_{\mathrm{s}}$ corresponds to the statistical distribution, $\Delta G_{\mathrm{e}}$ reflects the electrostatic repulsion between the positively charged metal ions, $\Delta G_{\mathrm{i}}$ accounts for the inductive factor related to the competitive coordination of the bridging ligand by the metal ions, $\Delta G_{\mathrm{r}}$ is the free energy of the resonance exchange, $\Delta G_{\mathrm{af}}$ relates to the antiferromagnetic exchange stabilization of the isovalent higher analogue state $\mathrm{M}^{n+1} \mathrm{M}^{n+1}$ over that of its mixed valent form $\mathrm{M}^{n} \mathrm{M}^{n+1}$ and $\Delta G_{\text {ip }}$ represents the ion-pairing effect, which changes its magnitude depending on the charge of the complex moiety. However, in the case of hole transfer mechanism, the value of $\Delta G_{\text {af }}$ becomes almost insignificant. Although $K_{\mathrm{c}}$ extends the prima facie information regarding the extent of the intermetallic interaction in a threestate arrangement, precautionary measures need to be taken into account. This is primarily due to the dependence of redox potentials on the nature of the solvent (dielectric constant or nucleophilicity) as well as counter ions (ion-pairing ability), which can affect the value of $\Delta G_{c}$ appreciably. ${ }^{24 b}$ Thus, to extract the extent of electronic coupling leading to valence localization or delocalization at the mixed valence state, the collective consideration of $K_{\mathrm{c}}$ and the intervalence charge transfer (IVCT) feature are rather necessary.

\subsection{Intervalence charge transfer (IVCT) transition}

In the case of a weakly coupled valence localized system, the charge transfer occurs from the metal in a lower oxidation state (electron rich) to the metal in a higher oxidation state (electron deficient), resulting in bridge-mediated uni-directional intervalence charge transfer transition (IVCT band) at the low-energy NIR region of electron absorption spectroscopy. ${ }^{25}$ The correlation of IVCT band with electronic coupling between the metal 
centers at the mixed valence state follows the Hush formula. ${ }^{26}$ For class II type complexes, the bandwidth at half-height $\left(\Delta \nu_{1 / 2}\right)$ of IVCT is related to the energy maximum (eqn (3)):

$$
\Delta \nu_{1 / 2}=\left[2.31 \times 10^{3}\left(E_{\max }\right)\right]^{1 / 2}
$$

In the case of a symmetrical band, IVCT can be correlated with the electronic coupling constant $\left(V_{\mathrm{ab}}\right)$ by eqn (4),

$$
V_{\mathrm{ab}}=\left\{\left[2.05 \times 10^{-2}\left(\varepsilon_{\max } \bar{v}_{\max } \bar{v}_{1 / 2}\right)^{1 / 2}\right] / R\right\}
$$

where $\varepsilon_{\max }$ is the molar extinction coefficient, $\bar{v}_{\max }$ is the absorption maximum in wavenumbers, $\bar{v}_{1 / 2}$ is the bandwidth at half-height in wavenumbers and $R$ is the metal-metal distance in $\AA$. However, the effective metal-metal distance can also vary significantly depending on the extent of the mixing of orbitals of the bridge and the metal ions at the termini. ${ }^{27}$

For a fully delocalized class III system, the calculated $\Delta \nu_{1 / 2}$ value of the IVCT band using the Hush equation is always higher than the experimentally obtained value, and $V_{\mathrm{ab}}$ amounts to $\bar{v}_{\text {max }} / 2$.

Please note that the valence localized class II system exhibits a double well potential. On the contrary, the extensive charge delocalization between the donor and acceptor sites in the class III system results in the disappearance of separate minima, exhibiting single minimum in the energy surface instead.

The larger bandwidth at half-height $\left(\Delta \nu_{1 / 2}\right)$ of IVCT for the weakly coupled (class II) system than that for the strongly coupled (class III) system can be due to the transition from the flat potential energy (PE) surface to a steep one in the former and the transition from the flat PE surface to another flat PE surface in the latter. ${ }^{15 b}$

In fact, the correlation between the IVCT band and the intermetallic coupling is not so straightforward as the band shape, bandwidth and intensity vary appreciably depending on the solvent polarity and electronic and vibrational motions. ${ }^{28,29}$ In the case of class III-type mixed valency, the motions from the solvent and vibrations are averaged to delocalize the electron density. This results in narrow solvent-independent IVCT bands. In class II-type, the IVCT band is broad and depends on the dielectric constant of the solvent as the motions from the exchange of electrons and the solvent are localized. On the contrary, in the borderline (hybrid) class II-III system, the solvent dynamic parameters play influential roles in controlling the rate of the intermolecular electron transfer by minimizing the impact of the solvent reorganization energy or polarity. ${ }^{23 b}$ Additionally, the parameter " $\Gamma$ " $\left(\Gamma=1-\left(\Delta \nu_{1 / 2}\right) /(16 \ln (2) R T)^{1 / 2}\right)$ introduced by Sutin and co-workers has been widely acknowledged in identifying the intriguing situation of the class II-III hybrid system. ${ }^{15 \boldsymbol{b}}$ The room-temperature limiting value of $\Gamma$ can distinguish between the weakly coupled class I $(0<\Gamma<0.1)$, moderately coupled class II $(0.1<\Gamma<0.5)$, class II-III hybrid $(I$ $\approx 0.5)$ and class III $(\Gamma>0.5)$ systems.

\subsection{Vibrational and electron spin resonance spectroscopy}

In this context, vibrational (IR and Raman) spectroscopic techniques have been considered to be very effective for the selectively designed molecular frameworks containing suitable functional groups such as $\mathrm{CO}, \mathrm{NO}$, and $\mathrm{CN}$ to extract more precise information relating to the valence localization or delocalization process at the mixed valence state with a faster picosecond to femtosecond time scale. ${ }^{30}$

The correlation of EPR $g$ parameters ( $g$-anisotropy, $\Delta g=g_{1}$ $-g_{3}$ and $\langle g\rangle=\left\{1 / 3\left(g_{1}{ }^{2}+g_{2}{ }^{2}+g_{3}{ }^{2}\right)\right\}^{1 / 2},{ }^{31}$ hyperfine splitting) with the DFT calculated spin density distribution at the metalbridge-metal domain of the paramagnetic mixed valence state provides additional justification in favor of the valence localization or delocalization process. ${ }^{32}$ However, a mixed valence state without any EPR response is not so uncommon, particularly due to the rapid relaxation process. This situation may improve upon moving to the liquid helium temperature $(4 \mathrm{~K}) \cdot{ }^{33}$

It should be noted that the time scale of a particular spectroscopic technique also plays a critical role in establishing the mixed valence feature. It may give rise to contradictory observations based on the rate of the electron transfer, solvent reorganization process and solvent dynamics. The slower time scale of the EPR spectroscopic technique $\left(10^{-5}\right.$ to $\left.10^{-9} \mathrm{~s}\right)$ often fails to distinguish the valence localized and delocalized situations, whereas a faster vibrational spectroscopy technique $\left(\sim 10^{-12} \mathrm{~s}\right)$ is found to be more precise in this regard. ${ }^{34}$

\subsection{Diruthenium complexes involving a redox active bridge}

In a specialized situation relating to the selective participation of bridge-based Frontier orbitals in the redox processes of the complex moieties, an additional complexity arises due to the probable alternate formation of a radical bridged isovalent state $\left(\left[(\mathrm{AL}) \mathrm{Ru}^{\mathrm{II}}(\mu-\mathrm{BL}) \mathrm{Ru}^{\mathrm{II}}(\mathrm{AL})\right]-\mathrm{e}^{-} \rightarrow\left[(\mathrm{AL}) \mathrm{Ru}^{\mathrm{II}}\left(\mu-\mathrm{BL}^{*}\right) \mathrm{Ru}^{\mathrm{II}}(\mathrm{AL})\right]^{+}\right)$ upon electron transfer instead of the otherwise expected mixed valence state $\left.\left(\left[(\mathrm{AL}) \mathrm{Ru}^{\mathrm{II}}(\mu-\mathrm{BL}) \mathrm{Ru}^{\mathrm{III}}(\mathrm{AL})\right]\right)\right)^{35}$ Therefore, appropriate care needs to be taken in formulating the electronic structure of the redox states as well. In this context, EPR $g$ anisotropy in conjunction with DFT-calculated spin distribution at the paramagnetic intermediate state can facilitate to differentiate the alternative mixed valence state versus the radical-bridged isovalent state.

The present review article highlights our recent observations concerning the divergent issues in addressing mixed valency in ligand-bridged diruthenium systems by citing the following representative cases.

\section{Metal-centered mixed valency}

\subsection{Role of the ancillary ligand}

Pyrazine-mediated facile intramolecular electron transfer in the mixed valent Creutz-Taube ion essentially leads to the development of analogous bis-tridentate non-planar 2,3,5,6tetrakis(2-pyridyl) pyrazine (tppz)-bridged isovalent diruthenium(II) complexes $\left(\left[(\mathrm{AL})(\mathrm{Cl}) \mathrm{Ru}^{\mathrm{II}}(\mu-\mathrm{tppz}) \mathrm{Ru}^{\mathrm{II}}(\mathrm{Cl})(\mathrm{AL})\right]^{n}\right.$, $\left.\mathbf{1}^{n}\right) .{ }^{36}$ The impact of a set of ancillary ligands (AL) with varying electronic demands in the mixed valent $\mathrm{Ru}^{\mathrm{II}} \mathrm{Ru}{ }^{\mathrm{III}}$ state $\left(\mathbf{1}^{n}\right)$ was explored (Table 1) via an experimental investigation in 
conjunction with DFT calculations. Successive two-step reversible electrochemical oxidations of isovalent $\mathrm{Ru}^{\mathrm{II}} \mathrm{Ru}^{\mathrm{II}}$ $\left(\mathbf{1}^{n}\right)$ complexes resulted in a mixed valent $\left\{\mathrm{Ru}^{\mathrm{II}}(\mu-\mathrm{tppz}) \mathrm{Ru}^{\mathrm{III}}\right\}$ intermediate $\left(\mathbf{1}^{(n+1)}\right)$ followed by the isovalent higher $\left\{\mathrm{Ru}^{\mathrm{III}}(\mu-\right.$ tppz) $\left.\mathrm{Ru}^{\mathrm{III}}\right\}^{\mathrm{I}}$ congener $\left(\mathbf{1}^{(n+2)}\right)$. The detailed structural, electrochemical, spectroscopic and theoretical investigations revealed that in addition to the bridge, the electronic nature ( $\sigma$-donating to $\pi$-acidic to strongly $\pi$-acidic) of the ancillary ligand (AL) also played an important role in tuning the mixed valence feature ( $K_{\mathrm{c}}$ as well as IVCT, Table 1$)$. The enhanced electron density on the metal ions via the insertion of an electron-rich ancillary ligand facilitated the intramolecular electron transfer process with larger $K_{\mathrm{c}}$ and intense IVCT (borderline class II-III to class III), whereas a reverse pattern (smaller $K_{\mathrm{c}}$ and weak IVCT) was apparent for the acceptor-type ancillary ligand. Please note that to the best of our knowledge, a well-defined valence-localized (weakly coupled) class II mixed valence system involving a tppz-bridged diruthenium system is not reported so far.

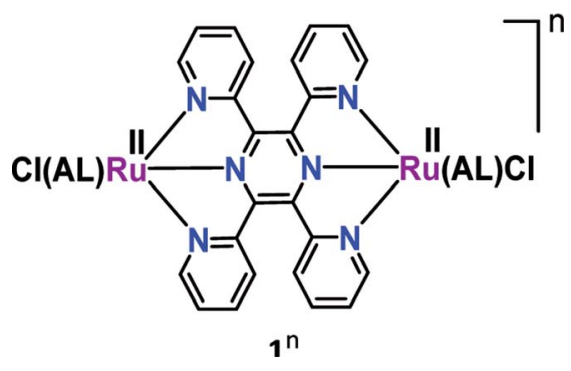

Table 1 Varying $K_{c}$ and IVCT as a function of the ancilliary ligand

$\left[\mathrm{Cl}(\mathrm{AL}) \mathrm{Ru}^{\mathrm{II}}(\mu-\mathrm{tppz}) \mathrm{Ru}^{\mathrm{III}}(\mathrm{AL}) \mathrm{Cl}\right]^{n}\left(\mathbf{1}^{n}\right)$

\begin{tabular}{|c|c|c|c|}
\hline AL & $K_{\mathrm{c}}$ & $\begin{array}{l}\nu_{\mathrm{IVCT}} / \mathrm{nm} \\
\left(\varepsilon / \mathbf{M}^{-1} \mathrm{~cm}^{-1}\right)\end{array}$ & Class $^{a}$ \\
\hline 2-Phenylazopyridine & $4.0 \times 10^{3}$ & $1890(3800)$ & II-III \\
\hline 2-[(4-Methylphenyl)azo]-pyridine & $2.1 \times 10^{4}$ & $1890(4600)$ & II-III \\
\hline 2-[(4-Chlorophenyl)azo]-pyridine & $2.2 \times 10^{3}$ & $1890(3000)$ & II-III \\
\hline 2,2/-Dipyridylamine & $2.7 \times 10^{6}$ & $1700(2250)$ & III \\
\hline 2-(2-Pyridyl)benzoxazole & $3.8 \times 10^{4}$ & $1635(1400)$ & II-III \\
\hline 2-(2-Pyridyl)benzthiazole & $5.6 \times 10^{4}$ & $1465(440)$ & II-III \\
\hline $\begin{array}{l}\text { 1-Methyl-2-(2-pyridyl)- } \\
\text { 1 } H \text {-benzimidazole }\end{array}$ & $2.6 \times 10^{4}$ & $1555(423)$ & II-III \\
\hline 2,2/-Dipyridylketone & $2.5 \times 10^{4}$ & $1800(1500)$ & II-III \\
\hline $\begin{array}{l}\text { 2,2/-bis(1-methylimidazolyl) } \\
\text { ketone }\end{array}$ & $1.2 \times 10^{5}$ & $1637(1200)$ & II-III \\
\hline 2-Picolinate & $4.0 \times 10^{6}$ & $1670(2600)$ & III \\
\hline 2-Quinolinecarboxylate & $8.9 \times 10^{6}$ & $1575(1200)$ & III \\
\hline 8-Quinolinecarboxylate & $1.9 \times 10^{7}$ & $1875(2600)$ & III \\
\hline Acetylacetonate & $10^{10}$ & $1680(2900)$ & III \\
\hline 3,5-Heptanedionate & $1.5 \times 10^{10}$ & $1688(3300)$ & III \\
\hline $\begin{array}{l}\text { 2,2,6,6-Tetramethyl-3, } \\
\text { 5-heptanedionate }\end{array}$ & $1.1 \times 10^{12}$ & $1750(3000)$ & III \\
\hline 3-Methyl-2,4-pentanedionate & $10^{10}$ & $1660(2300)$ & III \\
\hline 3-Ethyl-2,4-pentanedionate & $1.5 \times 10^{10}$ & $1674(2239)$ & III \\
\hline
\end{tabular}

${ }^{a}$ The classification (class III or class II-III) was defined primarily based on the $K_{\mathrm{c}}$ and IVCT band features by following the Hush formula as stated in Sections 1.3 and 1.4.

\section{2. $R u^{\mathrm{II}} \mathrm{Ru}^{\mathrm{III}}\left(\mathrm{d}^{6} \mathrm{~d}^{5}\right)$ versus $\mathrm{Ru}^{\mathrm{III}} \mathbf{R u ^ { \mathrm { IV } }}\left(\mathrm{d}^{5} \mathrm{~d}^{4}\right)$ mixed valence systems}

Though numerous examples of ligand-bridged $\mathrm{Ru}^{\mathrm{II}} \mathrm{Ru}^{\mathrm{III}}$ mixed valence systems are available in the literature, ${ }^{37}$ only a few welldefined $\mathrm{Ru}^{\mathrm{III}} \mathrm{Ru}^{\mathrm{IV}}$ mixed valence systems (D and E) are reported so far. ${ }^{38 b, c}$
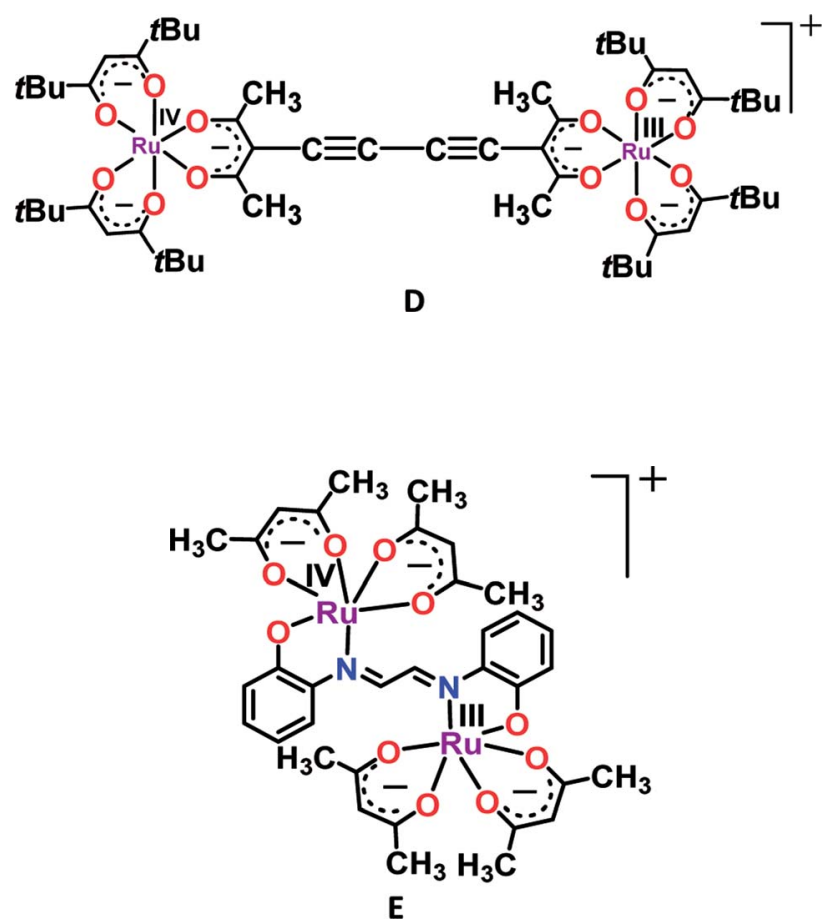

In this context, bis-chelating dianionic oxamidato-bridged diruthenium(III) complex $2^{n}(n=0)$ in $S=1$ ground state $\left(J=-40 \mathrm{~cm}^{-1}\right)$ exhibited two successive oxidative $\left(\mathrm{Ru}^{\mathrm{III}} \mathrm{Ru}^{\mathrm{III}}\right.$ $\left.(2) \rightarrow \mathrm{Ru}^{\mathrm{III}} \mathrm{Ru}^{\mathrm{IV}}\left(2^{+}\right) \rightarrow \mathrm{Ru}^{\mathrm{IV}} \mathrm{Ru}^{\mathrm{IV}}\left(2^{2+}\right), \mathrm{O} 1 / \mathrm{O} 2\right)$ and reductive $\left(\mathrm{Ru}^{\mathrm{III}} \mathrm{Ru}^{\mathrm{III}}(2) \rightarrow \mathrm{Ru}^{\mathrm{III}} \mathrm{Ru}^{\mathrm{II}}\left(2^{-}\right) \rightarrow \mathrm{Ru}^{\mathrm{II}} \mathrm{Ru}^{\mathrm{II}}\left(2^{2-}\right), \mathrm{R} 1 / \mathrm{R} 2\right)$ couples with moderate $K_{\mathrm{c}}$ values of $10^{5.8}$ and $10^{5.9}$ for mixed valent $\mathrm{Ru}^{\mathrm{III}} \mathrm{Ru}^{\mathrm{IV}}$ and $\mathrm{Ru}^{\mathrm{III}} \mathrm{Ru}^{\mathrm{II}}$, respectively (Fig. 5).

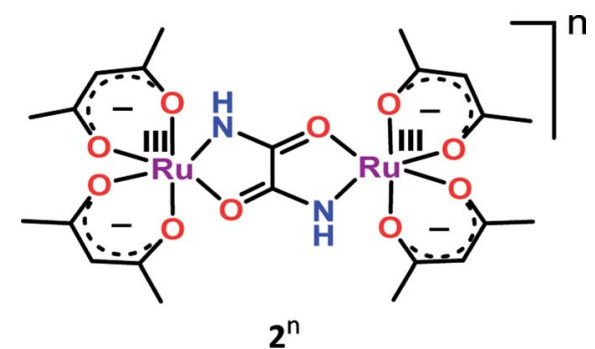

Both the electrochemically generated mixed valence states $\mathrm{Ru}^{\mathrm{III}} \mathrm{Ru}^{\mathrm{II}}\left(2^{-}\right)$and $\mathrm{Ru}^{\mathrm{III}} \mathrm{Ru}^{\mathrm{IV}}\left(2^{+}\right)$displayed moderately intense broad IVCT bands in the NIR region at $1800 \mathrm{~nm}\left(\varepsilon / \mathrm{M}^{-1} \mathrm{~cm}^{-1}\right.$ : $2100)$ and $1500 \mathrm{~nm}\left(\varepsilon / \mathrm{M}^{-1} \mathrm{~cm}^{-1}: 2200\right)$, respectively, corresponding to the class II system. The appearance of a relatively broader IVCT band for the $\mathrm{Ru}^{\mathrm{III}} \mathrm{Ru}^{\mathrm{IV}}\left(\mathrm{d}^{5} \mathrm{~d}^{4}\right)$ mixed valence state 


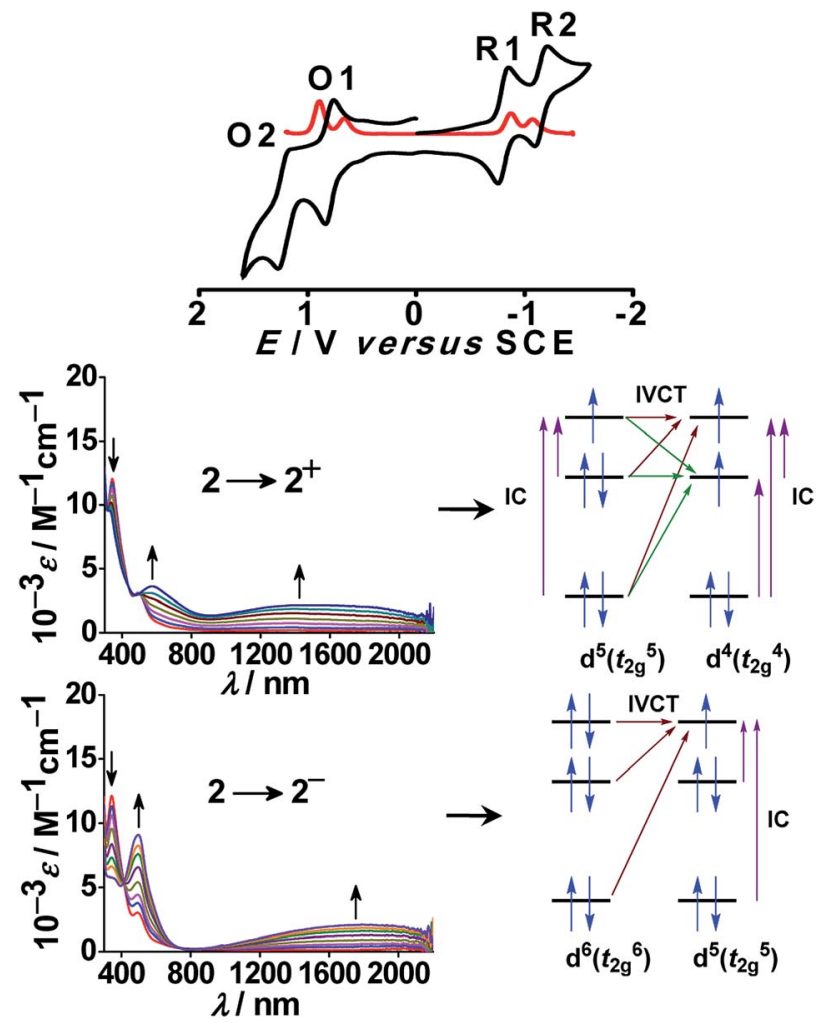

Fig. 5 Cyclic (black) and differential pulse (red) voltammograms of 2 in $\mathrm{CH}_{3} \mathrm{CN}$ (top). UV-vis-NIR spectroelectrochemistry in $\mathrm{CH}_{3} \mathrm{CN}$ and the sketch for IVCTT and IC transitions (bottom).

compared to that for the $\mathrm{Ru}^{\mathrm{III}} \mathrm{Ru}^{\mathrm{II}}\left(\mathrm{d}^{5} \mathrm{~d}^{6}\right)$ mixed valence state could possibly be due to more number of intervalence (IVCT) and d-d (IC) transitions in the former with respect to that in the latter because of the presence of three and one holes at metal $t_{2 g}$ levels, respectively (Fig. 5). Thus, $2^{n}$ represents a novel example demonstrating two mixed valence intermediates $\mathrm{Ru}^{\mathrm{III}} \mathrm{Ru}^{\mathrm{II}}$ (via reductive pathway) and less common $\mathrm{Ru}^{\mathrm{III}} \mathrm{Ru}^{\mathrm{IV}}$ (via oxidative pathway). ${ }^{38}$

\subsection{Paradox between $K_{\mathrm{c}}$ and IVCT}

According to the Robin and Day classification and Hush formalism, a symmetric class III molecular set is expected to display large $K_{\mathrm{c}}$ and an intense IVCT band in the NIR region. ${ }^{26,39}$ However, the mixed valent $\left(\mathrm{Ru}^{\mathrm{II}} \mathrm{Ru}^{\mathrm{III}}\right)$ complex $3^{+}$ failed to display the expected low-energy IVCT band up to $2500 \mathrm{~nm}$ despite the very large $K_{\mathrm{c}}$ value of $10^{13.9}{ }^{10}$ On the other hand, the previously reported analogous complex $\mathbf{4}^{+}$exhibited a solvent-independent and very weak IVCT band $\left(\varepsilon / \mathrm{M}^{-1} \mathrm{~cm}^{-1}\right.$ : 20) with a similar $K_{\mathrm{c}}$ value of $10^{13.6}{ }^{41}$ The absence of the IVCT band despite the very large $K_{\mathrm{c}}$ value in $\mathbf{3}^{+}$appeared to be rather puzzling. Though we were unable to offer any simple explanation, very weak to undetectable IVCT bands were also observed earlier for mixed valent ruthenium complexes with appreciably large $K_{c}$ values. ${ }^{42}$

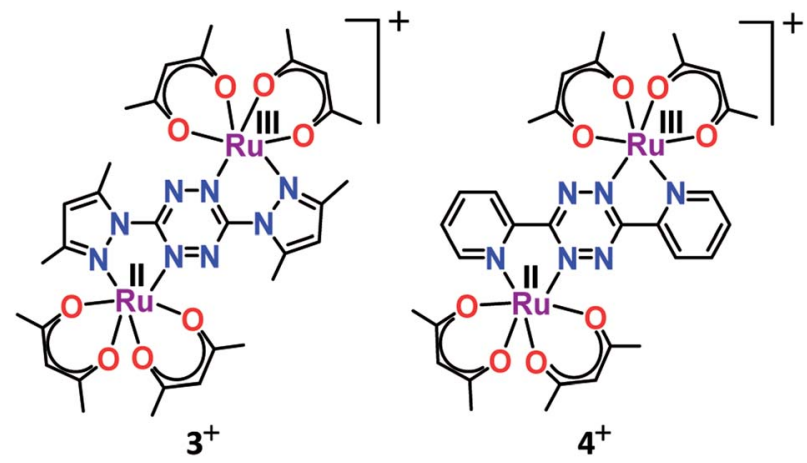

On the other hand, 2,5-pyrazine-dicarboxylate (BL)-bridged isovalent diruthenium(III) complex $\left(5^{n}(n=0)\right)$ (acac $=$ actylacetonate) in $S=1$ ground state $\left(J=-1.78 \mathrm{~cm}^{-1}\right)$ displayed successive $\mathrm{Ru}(\mathrm{III} / \mathrm{II})$ redox couples with $K_{\mathrm{c}}$ of $10^{7} .^{43}$ Stepwise one-electron reductions facilitated the generation of a mixedvalent intermediate $\left[(\mathrm{acac})_{2} \mathrm{Ru}^{\mathrm{III}}(\mu-\mathrm{BL}) \mathrm{Ru}^{\mathrm{II}}(\mathrm{acac})_{2}\right]^{-}\left(5^{-}\right)$followed by isovalent $\left[(\text { acac })_{2} \mathrm{Ru}^{\mathrm{II}}(\mu-\mathrm{BL}) \mathrm{Ru}^{\mathrm{II}}(\mathrm{acac})_{2}\right]^{2-}\left(5^{2-}\right)$ in lower oxidation states. The mixed valent $5^{-}$exhibited an $\mathrm{Ru}^{\text {III }}$ based anisotropic EPR spectrum $(\Delta g=0.32)$. However, the very weak IVCT band of the intermediate $5^{-}$at $1040 \mathrm{~nm}(\varepsilon=$ $380 \mathrm{M}^{-1} \mathrm{~cm}^{-1}$ ) implied limited electronic communication between the two metal centers $\left(\left\{\mathrm{Ru}^{\mathrm{III}}(\mu-\mathrm{BL}) \mathrm{Ru}^{\mathrm{II}}\right\}\right.$, class II) despite the appreciably high $K_{\mathrm{c}}$ value of $10^{7}$. The diverse inference regarding the mixed valence feature of $5^{-}$based on $K_{\mathrm{c}}$ (class III) and IVCT (class II) was however addressed via IR spectroelectrochemistry (Fig. 6). The unsplit $\nu(\mathrm{C}=\mathrm{O})$ bands of the carboxylate groups of BL for mixed valent $5^{-}$as those for isovalent 5 or $5^{2-}$ indeed suggested a delocalized $\left(\mathrm{Ru}^{2.5} \mathrm{Ru}^{2.5}\right.$, class III to borderline class II-III) situation even at the vibrational time scale.

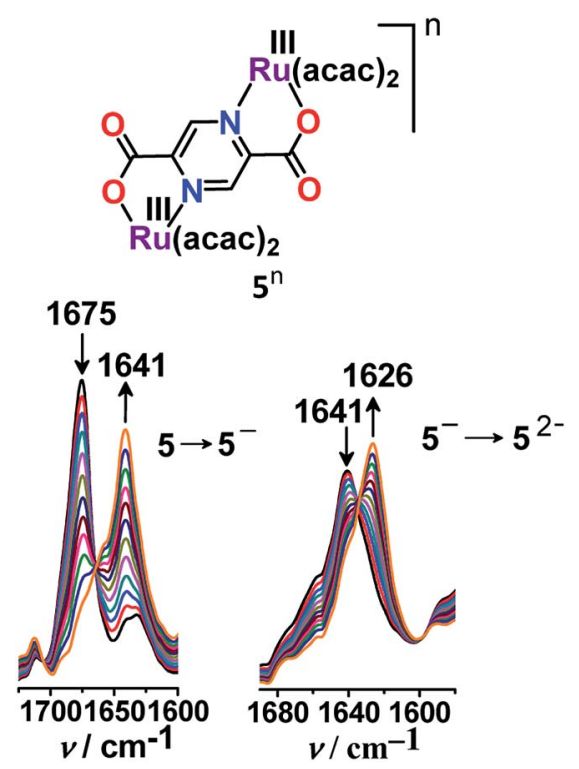

Fig. 6 Shift in the $\nu(\mathrm{C}=\mathrm{O})$ frequency on moving from $5 \rightarrow 5^{-}$and $5^{-}$ $\rightarrow 5^{2-}$ in $\mathrm{CH}_{3} \mathrm{CN}$. 
On the contrary, $6^{3+}$ and $7^{3+}$ exhibited intense IVCT bands despite small $K_{\mathrm{c}}$ values. ${ }^{44}$

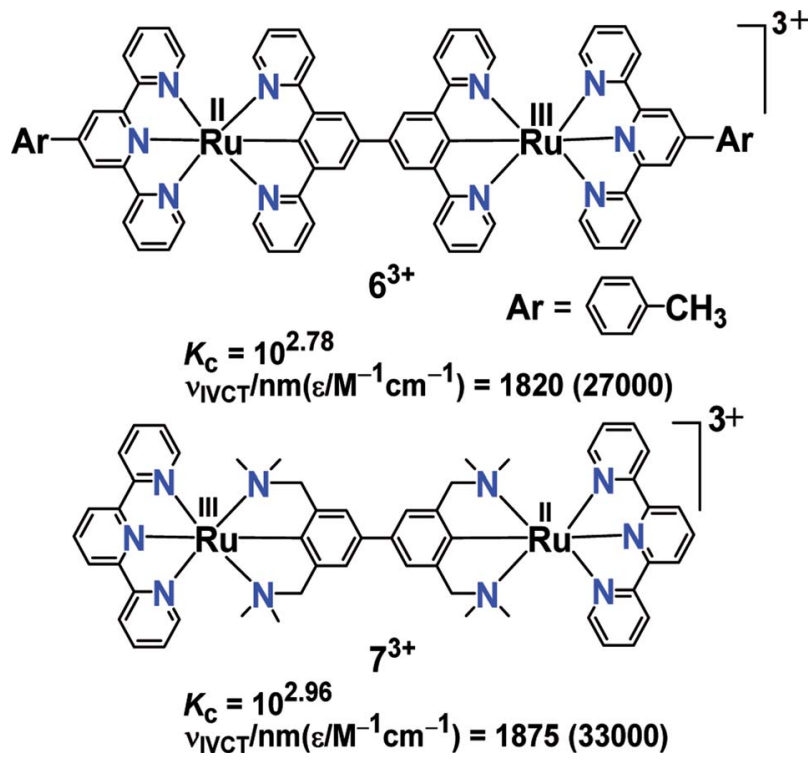

\subsection{Unsymmetrical diruthenium complexes}

Asymmetry in dinuclear frameworks can be introduced by using different ancillary ligands at the metal sites or by using an unsymmetrical bridge or even by coordination to two different metal ions. ${ }^{45}$ Unlike that in a symmetrical system, the donor center asymmetry (ancillary or bridging ligand) around the metal ions in an unsymmetrical system makes it rather challenging to quantify the contribution of intermetallic electrochemical coupling $\left(K_{\mathrm{c}}\right)$ out of the potential separation of the successive redox processes.

In this context, unsymmetrical diruthenium(II) complexes $\mathbf{8} \mathbf{a}^{2+}, \mathbf{8} \mathbf{b}^{2+}$ and $\mathbf{8 c}^{2+}$ exhibited two successive oxidation processes $\left(\mathrm{Ru}^{\mathrm{II}} \mathrm{Ru}^{\mathrm{II}} / \mathrm{Ru}^{\mathrm{II}} \mathrm{Ru}^{\mathrm{III}}\right.$ and $\left.\mathrm{Ru}^{\mathrm{II}} \mathrm{Ru}^{\mathrm{III}} / \mathrm{Ru}^{\mathrm{III}} \mathrm{Ru}^{\mathrm{III}}\right)$ via the intermediate mixed valent $\mathrm{Ru}^{\mathrm{II}} \mathrm{Ru}^{\mathrm{III}}$ state (Fig. 7). ${ }^{46}$ The separation in potential between the stepwise redox processes led to the $K_{\mathrm{c}}$ values of $10^{4}, 10^{2}$ and $10^{14}$ for the intermediates $\mathbf{8 a}^{3+}$, $\mathbf{8} \mathbf{b}^{3+}$ and $\mathbf{8} \mathbf{c}^{3+}$, respectively. The 100 -fold larger $K_{\mathrm{c}}$ value of $\mathbf{8 a}^{3+}$ with respect to that of $\mathbf{8} \mathbf{b}^{3+}$ was due to moderate and strong $\pi$ acceptor features of bpy and pap, respectively. On the other hand, the very large $K_{\mathrm{c}}$ value of $10^{14}$ for $\mathbf{8 c ^ { 3 + }}$, which comprised metal fragments with two distinctly different acceptor ligands bpy (moderate $\pi$ acceptor) and pap (strong $\pi$ acceptor) could be the reflection of three simultaneously operating effects: (i) effect of unsymmetrical ancillary ligand, (ii) effect of unsymmetrical bridging ligand and (iii) bridging ligand-mediated electrochemical coupling between the reduced and oxidized metal ions. The very weak IVCT band at the near IR region corresponding to $\mathbf{8 a}^{3+}$ and $\mathbf{8 b}^{3+}$ in conjunction with low $K_{\mathrm{c}}$ values of $10^{4}$ and $10^{2}$, respectively, suggested the class II mixed valence state. However, the unstable nature of the electrochemically generated $\mathbf{6} \mathbf{c}^{3+}$ restricted us from assigning its mixed valence feature.

Similarly, a cyano-bridged unsymmetric mixed valence ${ }^{\mathbf{4 5 g}}$ dinuclear complex $\left[\left(\mathrm{NH}_{3}\right)_{5}-\mathrm{Ru}-(\mu-\mathrm{CN}) \mathrm{Fe}(\mathrm{CN})_{5}\right]^{-}$involving
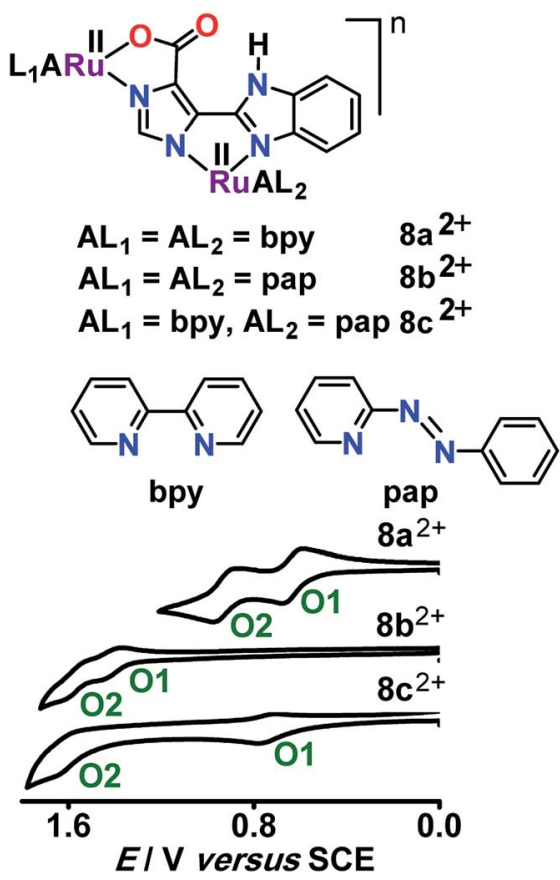

Fig. 7 Cyclic voltammograms of $8^{2+}$ in $\mathrm{CH}_{3} \mathrm{CN}$

different metal ions and ancillary ligands was assigned to be a valence-localized class-II system (eqn (5)) primarily based on its optical (IVCT) features and electrochemical aspects as a function of the solvent polarity and the charges of cations and anions of the electrolytes. ${ }^{45 f}$

$$
\begin{gathered}
{\left[\left(\mathrm{NH}_{3}\right)-\mathrm{Ru}^{\mathrm{III}}-(\mu-\mathrm{CN}) \mathrm{Fe}^{\mathrm{II}}(\mathrm{CN})_{5}\right]^{-} \stackrel{h v}{\rightarrow}} \\
\left(\left[\left(\mathrm{NH}_{3}\right)_{5}-\mathrm{Ru}^{\mathrm{II}}-(\mu-\mathrm{CN}) \mathrm{Fe}^{\mathrm{III}}(\mathrm{CN})_{5}\right]^{-}\right) *
\end{gathered}
$$

\section{Involvement of redox non- innocent ligands}

The closeness of the Frontier orbitals of ruthenium and redox active (non-innocent) ligands leads to the feasibility of alternate electronic structural forms including resonating configuration $^{47}$ instead of any precise valence description along the redox chain. $^{48}$ In certain instances, the redox-induced electron-transfer process (RIET) is also considered to be operational. ${ }^{49}$ Appropriate care is therefore needed in assigning the valence distribution process at the metal-ligand interface of such molecular forms.

A few representative cases involving multi-redox sites (metal, bridge or ancillary ligands) within the discrete molecular set up are therefore highlighted below.

\subsection{Active bridge and ancillary ligand}

Experimental and theoretical investigations of two successive reversible oxidation processes $(\mathrm{O} 1 / \mathrm{O} 2)$ of the deprotonated ellagate-bridged diruthenium(II) complex $9^{n}(n=0)$ (Fig. 8) revealed selective participation of bridge-based orbitals in the 

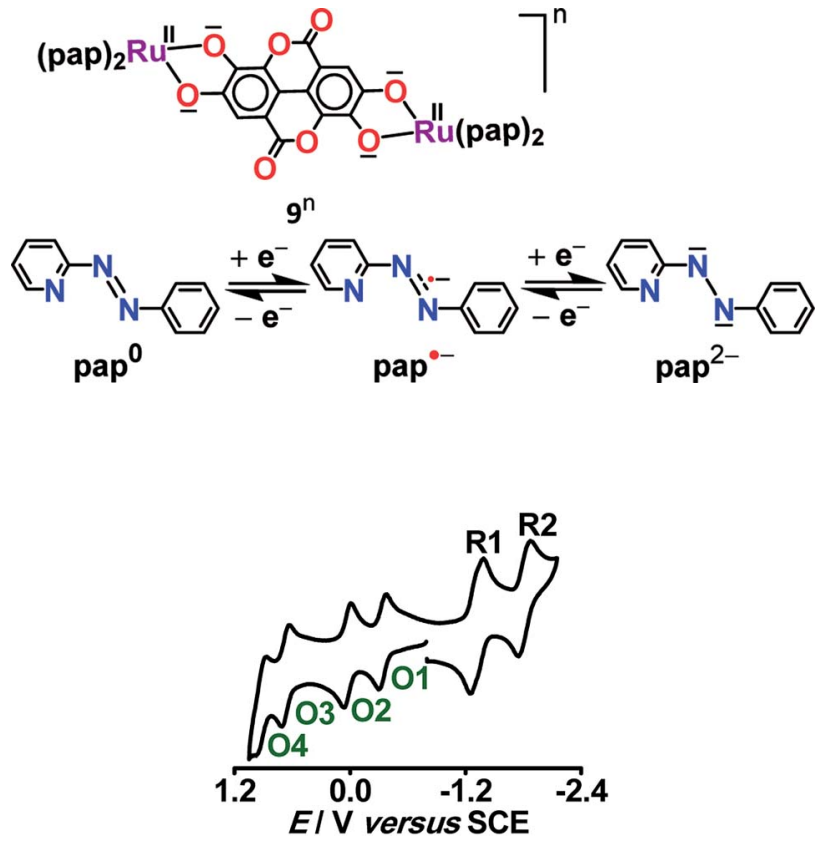

Fig. 8 Cyclic voltammograms of 9 in $\mathrm{CH}_{3} \mathrm{CN}$.

$$
\begin{aligned}
& 9^{2+} \quad(02): \quad(\text { pap })_{2} R^{\prime \prime}\left(\mu-B^{2-}\right) R u^{I l}(\text { pap })_{2} \\
& \begin{array}{c}
(S=1) \\
9^{+} \quad(01): \quad(\text { pap })_{2} R^{\prime \prime \prime}\left(\mu-\mathrm{e}^{-1}{ }^{* 3-}\right) \mathrm{Ru}^{-}(\text {pap })_{2} \\
(S=1 / 2)
\end{array} \\
& -e^{-1} \|_{t} e^{-} \\
& 9 \text { (native): } \quad(\text { pap })_{2} R u^{\prime \prime}\left(\mu-B L^{4-}\right) R u^{\prime l}(\text { pap })_{2} \\
& (S=0) \\
& -2 e^{-1}+2 e^{-} \\
& 9^{2-} \quad(R 1):\left(\text { pap }^{\circ-}\right)(\text { pap }) R u^{\prime \prime}\left(\mu-B L^{4-}\right) R u^{\prime \prime}(\text { pap })\left(\text { pap }^{\circ-}\right) \\
& \text { ( } S=1) \\
& -2 \mathrm{e}^{-1} \|+2 \mathrm{e}^{-} \\
& \begin{array}{c}
9^{4-} \quad \text { (R2): }\left(\text { pap }^{\bullet-}\right)_{2} \mathrm{Ru}^{\prime \prime}\left(\mu-\mathrm{BL}^{4-}\right) \mathrm{Ru}^{\mathrm{Il}}\left(\text { pap }^{\circ-}\right)_{2} \\
(S=2)
\end{array}
\end{aligned}
$$

Fig. 9 Electronic structural forms along the redox chain including the Mulliken spin density plot for $9^{+}$.

redox processes $\left(\mathbf{9} \rightarrow \mathbf{9}^{+}(\mathrm{O} 1)\right.$ and $\mathbf{9}^{+} \rightarrow \mathbf{9}^{2+}(\mathrm{O} 2)$ in Fig. 8), i.e. a catecholate/semiquinone-based redox system instead of otherwise expected metal-based $\left(\mathrm{Ru}^{\mathrm{II}} / \mathrm{Ru}^{\mathrm{III}}\right)$ oxidations. ${ }^{50}$ The intermediate radical-bridged isovalent metal $\left(\mathrm{Ru}^{\mathrm{II}}\right)$ centers in $\mathbf{9}^{+}$ exhibited free radical EPR $\left(g_{1}=2.011, g_{2}=2.002, g_{3}=1.987 ; \Delta g\right.$ $=0.024,\langle g\rangle=2.000$ ), which was corroborated by the calculated bridge-dominated spin (96\%) and the intense LLCT (donor radical bridge to $\pi$-accepting pap) transitions in the NIR region around $2000 \mathrm{~nm}\left(\varepsilon / \mathrm{M}^{-1} \mathrm{~cm}^{-1}\right.$ : 1843) (Fig. 8). Successive reductions (R1 $\left(\mathbf{9}^{2-}\right), \mathrm{R} 2\left(\mathbf{9}^{4-}\right)$, two-electron each) of the fully reduced bridge-based 9 were however associated with the azo $(-\mathrm{N}=\mathrm{N}-$, $\mathrm{pap}^{0} / \mathrm{pap}^{--} / \mathrm{pap}^{2-}$, as shown above) function of pap (Fig. 9).

\subsection{Active ancillary ligand}

Structural, spectroscopic and magnetic studies showed that the uncoupled semiquinone ancillary ligands stabilized the tppzbridged diruthenium(II) complex $\mathbf{1 0}^{n}(n=0)$ in the triplet $(S=$ $1, J=-3.07 \mathrm{~cm}^{-1}$ ) ground state. ${ }^{51}$ Stepwise oxidations $(\mathrm{O} 1, \mathrm{O} 2)$ and reductions (R1, R2) of complex 10 yielded the calculated $K_{\mathrm{c}}$ values of $10^{2}$ and $10^{4}$, respectively, for the intermediate states (Fig. 10). The pertinent question regarding the involvement of ancillary ligand (quinone $(\mathrm{Q})$, semiquinone $\left(\mathrm{Q}^{-}\right)$and catecholate $\left(\mathrm{Q}^{2-}\right)$ ), bridge $\left(\mathrm{tppz}^{\mathrm{O}}, \mathrm{tppz}^{\cdot-}, \mathrm{tppz}^{2-}\right)$ and metal $\left(\mathrm{Ru}^{\mathrm{II}}, \mathrm{Ru}^{\mathrm{III}}, \mathrm{Ru}^{\mathrm{IV}}\right)$
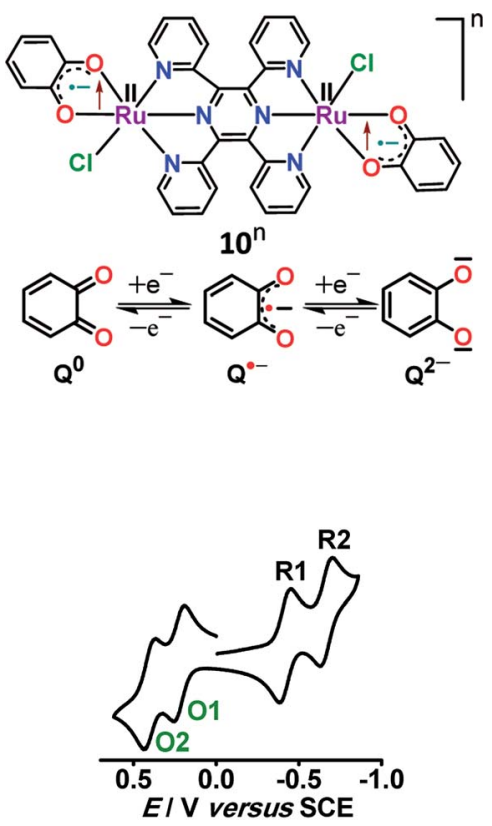

Fig. 10 Cyclic voltammogram of 10 in $\mathrm{CH}_{3} \mathrm{CN}$.

$$
\begin{aligned}
& 10^{2+}(\mathrm{O} 2):\left[\left(\mathrm{L}^{0}\right) \mathrm{R} \mathbf{u}^{\mathrm{II}} \mathrm{CI}(\mu-\mathrm{tppz}) \mathrm{CIR} \mathbf{u}^{\mathrm{II}}\left(\mathrm{L}^{0}\right)\right]^{2+}
\end{aligned}
$$

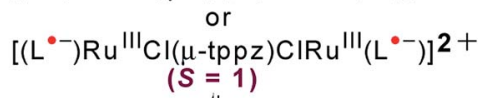

$$
\begin{aligned}
& -\mathrm{e}^{-} \|+\mathrm{e}^{-} \\
& 10^{+}(01):\left[\left(\mathrm{L}^{0}\right) \mathrm{R} \mathbf{u}^{\mathrm{II}} \mathrm{CI}(\mu-\operatorname{tpp}) \mathrm{CIR} \mathbf{u}^{\prime \prime}\left(\mathrm{L}^{\bullet-}\right)\right]^{+} \\
& {\left[\left(\mathrm{L}^{\bullet-}\right) \mathrm{Ru}{ }^{\prime \prime} \mathrm{CI}(\mu-\operatorname{tpp} z) \mathrm{CIRu}^{\mathrm{III}}\left(\mathrm{L}^{\bullet-}\right)\right]^{+}} \\
& (S=1 / 2) \\
& -\mathrm{e}^{-} \|+\mathrm{e}^{-} \\
& \left.\left.10 \text { (native): [( } \mathrm{L}^{--}\right) \mathrm{Ru} \mathrm{u}^{\mathrm{II}} \mathrm{CI}(\mu-\operatorname{tpp} \mathrm{C}) \mathrm{CIRu^{ \prime \prime }}\left(\mathrm{L}^{\bullet-}\right)\right] \\
& \text { ( } S=1) \\
& -\mathrm{e}^{-1}+\mathrm{e}^{-} \\
& 10^{-} \quad(\mathrm{R} 1):\left[\left(\mathrm{L}^{2-}\right) \mathrm{R} \mathrm{u}^{\mathrm{III}} \mathrm{CI}(\mu-\operatorname{tpp} z) \mathrm{CIR} \mathrm{u}^{\prime \prime}\left(\mathrm{L}^{2-}\right)\right]^{-} \\
& \text {or } \\
& {\left[\left(\mathrm{L}^{2-}\right) \mathrm{Ru}{ }^{\mathrm{II}} \mathrm{CI}(\mu-\mathrm{tpp} z) \mathrm{CIRu} \mathrm{u}^{\mathrm{II}}\left(\mathrm{L}^{\bullet-}\right)\right]} \\
& \text { ( } S=1 / 2) \\
& -\mathrm{e}^{-} \hat{\psi}+\mathrm{e}^{-} \\
& 10^{2-}(\mathrm{R} 2):\left[\left(\mathrm{L}^{2-}\right) \mathrm{R} u^{\mathrm{II}} \mathrm{CI}(\mu-\operatorname{tpp} z) \mathrm{CIR} \mathrm{u}^{\mathrm{II}}\left(\mathrm{L}^{2-}\right)\right]^{2-} \\
& (S=0)
\end{aligned}
$$

Fig. 11 Electronic structural forms of $10^{n}$ in accessible redox states. Boldface refers to the dominating forms. 
in accessible redox processes of $\mathbf{1 0}^{n}$ was ascertained via the collective consideration of experimental and theoretical investigations. It revealed the preferential participation of ancillary ligands in both oxidation $\left(\mathrm{Q}^{\cdot-}\right.$ to $\left.\mathrm{Q}^{0}\right)$ and reduction $\left(\left(\mathrm{Q}^{\cdot-}\right.\right.$ to $\left.\left.\mathrm{Q}^{2-}\right)\right)$ processes, leaving the metal ion as the silent spectator (Fig. 11).
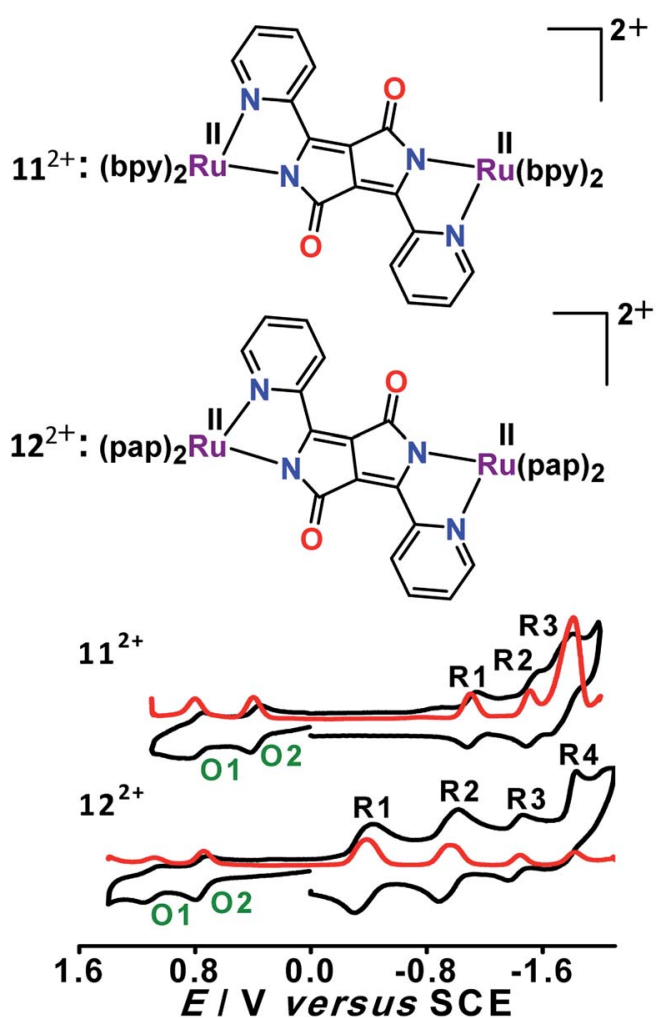

Fig. 12 Cyclic (black) and differential pulse (red) voltammograms in $\mathrm{CH}_{3} \mathrm{CN}$.

$$
\begin{aligned}
& 11^{4+} / 12^{4+} \quad(02):\left[L_{2} R^{2.5}\left(\mu-D^{4} P P^{\circ-}\right) R^{2.5} L_{2}\right]^{4+} \\
& \text { ( } S=1) \\
& -\mathrm{e}^{-} \|+\mathrm{e}^{-} \\
& 11^{3+} / 12^{3+} \quad(01): \quad\left[\mathrm{L}_{2} \mathrm{Ru}^{\mathrm{II}}\left(\mu-\mathrm{DPPP} \mathrm{P}^{\circ-}\right) \mathrm{Ru}^{\mathrm{II}} \mathrm{L}_{2}\right]^{3+} \\
& \begin{array}{l}
(S=1 / 2) \\
-e^{-} \|+e^{-}
\end{array} \\
& 11^{2+} / 12^{2+} \text { (native): } \quad\left[\mathrm{L}_{2} \mathrm{Ru}^{\prime \prime}\left(\mu-\mathrm{DPPP}^{2-}\right) \mathrm{Ru}^{\mathrm{Il}} \mathrm{L}_{2}\right]^{2+} \\
& \text { ( } S=0 \text { ) } \\
& -e^{-} \|+e^{-}
\end{aligned}
$$

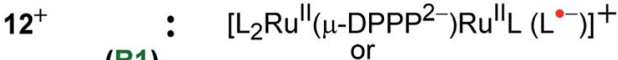

$$
\begin{aligned}
& 11^{+}: \quad\left[\mathrm{L}_{2} \mathrm{Ru}^{\mathrm{II}}\left(\mu-\mathrm{DPPP}^{\circ 3-}\right) \mathrm{Ru}^{\mathrm{Il}} \mathrm{L}_{2}\right]^{+}(\mathrm{L}=\mathrm{bpy}) \\
& (S=1 / 2) \\
& -\mathrm{e}^{-1} \|+\mathrm{e}^{-}
\end{aligned}
$$

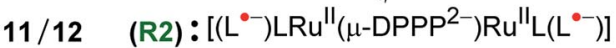

$$
\begin{aligned}
& \text { ( } S=1)
\end{aligned}
$$

Fig. 13 Electronic structural forms of $11^{n}$ and $12^{n}$.

\subsection{Active bridge, ancillary ligand and metal}

Dianionic $\mathrm{DPPP}^{2-} \quad\left(\mathrm{H}_{2} \mathrm{DPPP}=\right.$ 2,5-dihydro-3,6-di-2-pyridylpyrrolo[3,4-c]pyrrole-1,4-dione)-bridged diruthenium(II) complexes $\mathbf{1 1}^{2+}$ and $\mathbf{1 2}^{2+}$ displayed two successive oxidations and multiple reductions within the potential window of $\pm 2.0 \mathrm{~V}$ versus SCE (Fig. 12). ${ }^{52}$ DFT and TD-DFT-supported experimental studies established bridge-based first oxidation $\left(\mathrm{DPPP}^{2-} \rightarrow\right.$ $\mathrm{DPPP}^{\cdot-}$ (O1, Fig. 12)), followed by metal oxidation (O2, Fig. 12), whereas the first two reversible reductions were associated with $\mathrm{DPPP}^{2-}\left(\mathrm{DPPP}^{2-} \rightarrow \mathrm{DPPP}^{\cdot 3-}\right)$ or the ancillary ligand based on the relative $\pi$-accepting strength of the latter (bpy versus pap) (Fig. 13).

The occurrence of the radical-bridged isovalent situation along the redox chain was also evident by free radical EPR ( $g_{\text {iso }}$ $=\sim 2.005$ ) and the moderately intense inter-ligand (LLCT) lowenergy band in the NIR region $\left(2036 \mathrm{~nm},\left(\varepsilon / \mathrm{M}^{-1} \mathrm{~cm}^{-1}: 2410\right)\right.$.

\subsection{Unusual spin interaction}

Twisted doubly reduced $\mathrm{BL}^{2-}\left(\mathrm{BL}^{2-}=1,4\right.$-dioxido-2,3-bis(3,5dimethylpyrazol-1'-yl)benzene)-bridged $\left[(\text { acac })_{2} \mathrm{Ru}^{\mathrm{III}}(\mu-B \mathrm{~L}) \mathrm{Ru}^{\mathrm{III}}\right.$ $\left.(\text { acac })_{2}\right]^{n}\left(13^{n}(n=0)\right)$ (acac $=$ acetylacetonate) in $S=1$ state $(J=$ $-37 \mathrm{~cm}^{-1}$ ) exhibited two successive oxidations (O1, O2) and reductions (R1, R2) (Fig. 14). ${ }^{53}$

UV-vis-NIR spectroelectrochemistry (Fig. 15) and EPR (Fig. 16) collectively corroborated metal-based reductions, $\mathrm{Ru}^{\mathrm{III}} \mathrm{Ru}^{\mathrm{III}}(13) \rightarrow \mathrm{Ru}^{\mathrm{III}} \mathrm{Ru}^{\mathrm{II}}\left(13^{-}, \mathrm{R} 1\right) \rightarrow \mathrm{Ru}^{\mathrm{II}} \mathrm{Ru}^{\mathrm{II}}\left(13^{2-}, \mathrm{R} 2\right)$. The mixed valent $13^{-}$displayed an anisotropic $\mathrm{Ru}^{\mathrm{III}}$-based EPR spectrum $\left(g_{1}=2.40, g_{2}=2.19, g_{3}=1.79 ; \Delta g=0.061,\langle g\rangle=2.14\right)$ and a broad IVCT band at $1520 \mathrm{~nm}\left(\varepsilon / \mathrm{M}^{-1} \mathrm{~cm}^{-1}: 1000 ; \Delta \nu_{1 / 2}\right.$ (calculated/experimental): $3898 / 5000 \mathrm{~cm}^{-1}$ ), corresponding to the valence localized class II system, as also suggested by $K_{\mathrm{c}}$ of $10^{3.7}$. However, the IVCT band of $13^{-}$disappeared on further reduction to the isovalent $\mathrm{Ru}^{\mathrm{II}} \mathrm{Ru}^{\mathrm{II}}$ state in $13^{2-}$. A reversible first oxidation $\left(\mathrm{O} 1, \mathbf{1 3} \rightarrow \mathbf{1 3}^{+}\right)$resulted in an intense NIR band at $892 \mathrm{~nm}\left(\varepsilon / \mathrm{M}^{-1} \mathrm{~cm}^{-1}: 11600\right)$ and a free radical EPR at $g=$

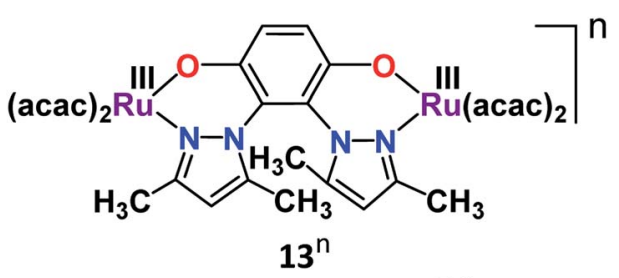

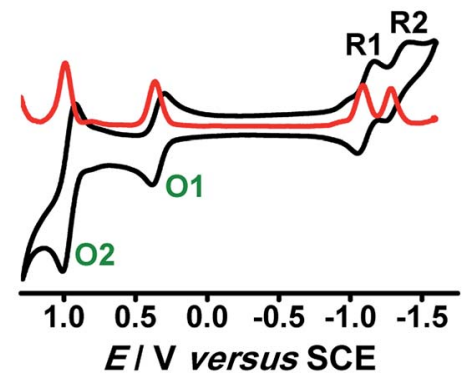

Fig. 14 Cyclic (black) and differential pulse (red) voltammograms of 13 in $\mathrm{CH}_{3} \mathrm{CN}$. 


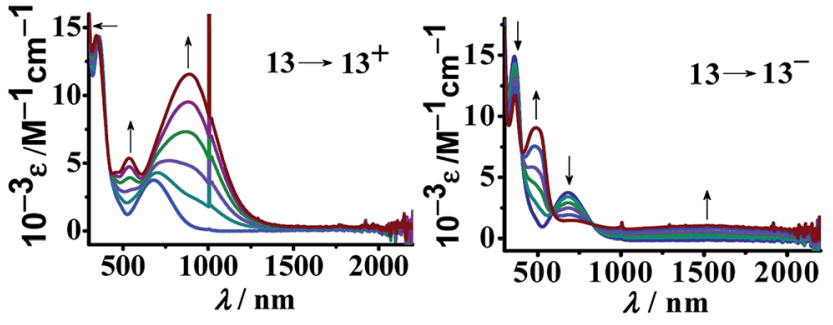

Fig. 15 UV-vis-NIR spectroelectrochemistry of $13^{n}$ in $\mathrm{CH}_{3} \mathrm{CN}$.

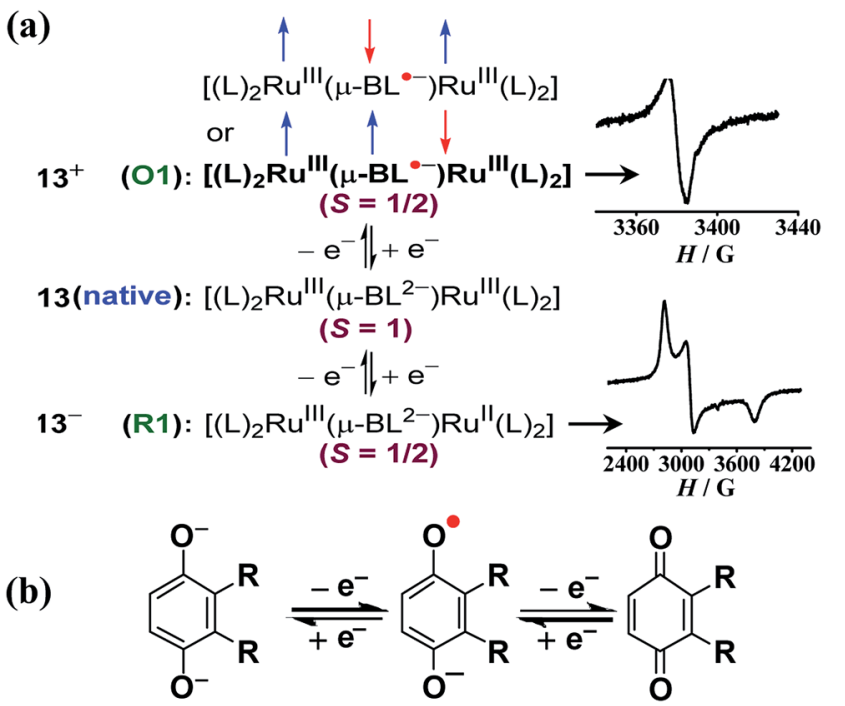

Fig. 16 (a) Electronic structural forms of $13^{n}$ with EPR for the $S=1 / 2$ state in $\mathrm{CH}_{3} \mathrm{CN}$. Boldface refers to the correct form. (b) Redox states of the para-quinone unit.

2.005. The observed free radical EPR of $\mathbf{1 3}^{+}$could be rationalized by considering the electronic form of $\left[(\mathrm{acac}){ }_{2} \mathrm{Ru}^{\mathrm{III}}(\mu-\right.$ $\left.\left.\mathrm{BL}^{-}\right) \mathrm{Ru}^{\mathrm{III}}(\mathrm{acac})_{2}\right]^{+}$with an up-up-down $(\uparrow \uparrow \downarrow)$ spin configuration, where the antiferromagnetic coupling between the remote metal spins left the unpaired spin on the bridge. The alternate three-spin arrangement with the up-down-up $(\uparrow \downarrow \uparrow)$ spin configuration in the ground state would favor metalcentered spin through antiferromagnetic coupling between the spins associated with one of the ruthenium ions and the radical bridge.

\section{Conclusion and perspectives}

Although mixed valence aspects of transition metal complexes have been covered quite extensively in existing literature, the present deliberation indicates the further scope of expansion depending on the conspicuous nature of the bridge in a threestate mixed valence system.

The present review article essentially highlighted the emerging diverse fundamental aspects relating to the mixed valency in ligand-bridged symmetric and unsymmetric diruthenium complexes by citing selective recent cases. It demonstrated the impact of the electronic nature of both ancillary and bridging ligands in tuning the intramolecular electron transfer process at the mixed valence state $\left(\mathrm{Ru}^{\mathrm{II}} \mathrm{Ru}^{\mathrm{III}}\right.$ or $\left.\mathrm{Ru}^{\mathrm{III}} \mathrm{Ru}^{\mathrm{IV}}\right)$. It also addressed the pertinent additional issues regarding valence and spin situations due to the introduction of redox active ligands in complex frameworks. Moreover, the necessary cautions with special references to the comproportionation constant $\left(K_{\mathrm{c}}\right)$ and the possible low-energy (NIR) ligand-to-ligand charge transfer (LLCT) transition instead of the usual metal-based IVCT transition for redox-active ligandderived systems were noted.

Besides the well explored application potential of mixed valence complexes for molecular wires, ${ }^{54}$ molecular switches ${ }^{55}$ or telecommunication devices, ${ }^{56}$ the recent revelations of superior conductivity of transition metal-derived metalorganic frameworks (beyond the classical discrete metal complexes) due to better orbital overlapping at the mixed valent state ${ }^{57}$ as well as involvement of mixed valent state in the water oxidation process $^{58}$ would provide additional impetus in developing more fundamentally challenging or attractive mixed valent systems.

Thus, further research activities with fundamentally rich and diversified mixed valence compounds would likely expand the scope of designing new generation molecular electronic devices and provide a better understanding of the electron transfer phenomenon in a complex molecular set up.

\section{Conflicts of interest}

There are no conflicts to declare.

\section{Acknowledgements}

Financial support received from Science and Engineering Research Board (SERB, Department of Science and Technology) and University Grant Commission (Fellowship to A. S. H), New Delhi, India, is gratefully acknowledged. Contributions of all the co-authors are also gratefully acknowledged.

\section{Notes and references}

1 (a) D. B. Brown, Mixed Valency Systems-Applications in Chemistry, Physics and Biology, ed. K. Prassides, Kluwer Academic Publishers, Dordrecht, 1991; (b) S. F. Nelsen, Chem.-Eur. J., 2000, 6, 581; (c) P. Aguirre-Etcheverry and D. O'Hare, Chem. Rev., 2010, 110, 4839; (d) P. J. Low and N. J. Brown, J. Cluster Sci., 2010, 21, 235; (e) M. H. Chisholm and B. J. Lear, Chem. Soc. Rev., 2011, 40, 5254; $(f)$ A. Hildebrandt and H. Lang, Organometallics, 2013, 32, 5640; (g) W. Kaim, A. Klein and M. Glöckle, Acc. Chem. Res., 2000, 33, 755.

2 (a) L. L. Miller and K. R. Mann, Acc. Chem. Res., 1996, 29, 417; (b) D.-L. Sun, S. V. Rosokha, S. V. Lindeman and J. K. Kochi, J. Am. Chem. Soc., 2003, 125, 15950; (c) J. Casado, K. Takimiya, T. Otsubo, F. J. Ramirez, J. J. Quirante, R. P. Ortiz, S. R. Gonzalez, M. M. Oliva and 
J. T. L. Navarrete, J. Am. Chem. Soc., 2008, 130, 14028; (d) D. Cornelis, E. Franz, I. Asselberghs, K. Clays, T. Verbiest and G. Koeckelberghs, J. Am. Chem. Soc., 2011, 133, 1317; (e) S. P. Jagtap, S. Mukhopadhyay, V. Coropceanum, G. L. Brizius, J.-L. Bredas and D. M. Collard, J. Am. Chem. Soc., 2012, 134, 7176; (f) S. T. Schneebeli, M. Frasconi, Z. Liu, Y. Wu, D. M. Gardner, N. L. Strutt, C. Cheng, R. Carmieli, M. R. Wasielewski and J. F. Stoddart, Angew. Chem., Int. Ed., 2013, 52, 13100.

3 (a) V. Krewald, M. Retegan, N. Cox, J. Messinger, W. Lubitz, S. DeBeer, F. Neese and D. A. Pantazis, Chem. Sci., 2015, 6, 1676; (b) A. Klauss, M. Haumann and H. Dau, Proc. Natl. Acad. Sci., 2012, 109, 16035; (c) T. A. Roelofs, W. Liang, M. J. Latimer, R. M. Cinco, A. Rompel, J. C. Andrews, K. Sauer, V. K. Yachandra and M. P. Klein, Proc. Natl. Acad. Sci., 1996, 93, 3335-3340.

4 (a) R. Boelens and R. Wever, FEBS Lett., 1980, 116, 223; (b) D. A. Proshlyakov, M. A. Pressler and G. T. Babcock, Proc. Natl. Acad. Sci. U. S. A., 1998, 95, 8020.

5 (a) H. Beinert, R. H. Holm and E. Münck, Science, 1997, 277, 653; (b) S. Subramanian, E. C. Duin, S. E. J. Fawcett, F. A. Armstrong, J. Meyer and M. K. Johnson, J. Am. Chem. Soc., 2015, 137, 4567; (c) S. Rumpel, J. F. Siebel, M. Diallo, C. FarÀs, E. J. Reijerse and W. Lubitz, ChemBioChem, 2015, 16, 1663-1669; (d) M.-E. Pandelia, D. Bykov, R. Izsak, P. Infossi, M.-T. G. Orticoni, E. Bill, F. Neese and W. Lubitz, Proc. Natl. Acad. Sci., 2013, 110, 483.

6 (a) H. Dau, A. Grundmeier, P. Loja and M. Haumann, Philos. Trans. R. Soc., B, 2008, 363, 1237-1244; (b) A. Indra, P. W. Menezes and M. Driess, ChemSusChem, 2015, 8, 776.

7 (a) J. M. D. Coey and M. Viret, Adv. Phys, 1999, 48, 167; (b) G. Subías, J. García, J. Blasco, M. G. Proietti, H. Renevier and M. C. Sánchez, Phys. Rev. Lett., 2004, 93, 156408; (c) T. Mochida, E. Nagabuchi, M. Takahashi and H. Mori, Chem. Commun., 2014, 50, 2481; (d) A. Dey, X. Xie and E. I. Solomon, Chem. Soc. Rev., 2008, 37, 623.

8 H. He, Y. Zhong, X. Liang, W. Tan, J. Zhu and C. Y. Wang, Sci. Rep., 2015, 5, 10139.

9 (a) J. M. Herrera, A. Bachschmidt, F. Villain, A. Bleuzen, V. Marvaud, W. Wernsdorfer and M. Verdaguer, Philos. Trans. R. Soc., A, 2008, 366, 127; (b) D. M. Rogers and J. O. Johansson, Mater. Sci. Eng. B, 2018, 227, 28; (c) P. W. Menezes, A. Indra, D. González-Flores, N. R. Sahraie, I. Zaharieva, M. Schwarze, P. Strasser, H. Dau and M. Driess, ACS Catal., 2015, 5, 2017; (d) A. Indra, P. W. Menezes, C. Das, D. Schmeißer and M. Driess, Chem. Commun., 2017, 53, 8641; (e) P. W. Menezes, A. Indra, V. Gutkin and M. Driess, Chem. Commun., 2017, 53, 8018; (f) A. Indra, P. W. Menezes, N. R. Sahraie, A. Bergmann, C. Das, M. Tallarida, D. Schmeißer, P. Strasser and M. Driess, J. Am. Chem. Soc., 2014, 136, 17530; $(g)$ A. Indra, P. W. Menezes, C. Das, C. Göbel, M. Tallarida, D. Schmeißer and M. Driess, J. Mater. Chem. A, 2017, 5, 5171.
10 (a) M. B. Solomon, T. L. Church and D. M. D'Alessandro, CrystEngComm, 2017, 19, 4049; (b) A. Indra, U. Paik and T. Song, Angew. Chem., Int. Ed., 2018, 57, 1241.

11 (a) C. Creutz and H. Taube, J. Am. Chem. Soc., 1969, 91, 3988; (b) C. Creutz and H. Taube, J. Am. Chem. Soc., 1973, 95, 1086; (c) U. Fuerholz, H. B. Buergi, F. E. Wagner, A. Stebler, J. H. Ammeter, E. Krausz, R. J. H. Clark, M. J. Stead and A. Ludi, J. Am. Chem. Soc., 1984, 106, 121.

12 (a) C. Levanda, K. Bechgaard and D. Cowan, J. Org. Chem., 1976, 41, 2700; (b) D. O. Cowan and F. Kaufman, J. Am. Chem. Soc., 1970, 92, 219-220; (c) T. M. Westerhoff, Angew. Chem., Int. Ed., 1986, 25, 702-717.

13 R. D. McCullough, G. B. Kok, K. A. Lerstrup and D. O. Cowan, J. Am. Chem. Soc., 1987, 109, 4115.

14 W. Kaim and G. K. Lahiri, Angew. Chem., Int. Ed., 2007, 46, 1778 and references therein.

15 (a) H. Taube, Angew. Chem., Int. Ed., 1984, 23, 329; (b) B. S. Brunschwig, C. Creutz and N. Sutin, Chem. Soc. Rev., 2002, 31, 168; (c) B. S. Brunschwig and N. Sutin, Coord. Chem. Rev., 1999, 187, 233; (d) D. E. Richardson and H. Taube, Coord. Chem. Rev., 1984, 60, 107; (e) D. O. Cowan, C. LeVanda, J. Park and F. Kaufman, Acc. Chem. Res., 1973, 6, 1.

16 (a) S. B. Braun-Sand and O. Wiest, J. Phys. Chem. A, 2003, 107, 285; (b) C. S. Lent, B. Isaksen and M. Lieberman, J. Am. Chem. Soc., 2003, 125, 1056; (c) A. Burgun, B. G. Ellis, T. Roisnel, B. W. Skelton, M. I. Bruce and C. Lapinte, Organometallics, 2014, 33, 4209.

17 (a) M. Sturza, C. D. Malliakas, D. E. Bugaris, F. Han, D. Y. Chung and M. G. Kanatzidis, Inorg. Chem., 2014, 53, 12191; (b) K. Himoto, S. Suzuki, T. Okubo, M. Maekawa and T. Kuroda-Sowa, New J. Chem., 2018, 42, 3995.

18 (a) J. P. Launay, Chem. Soc. Rev., 2001, 30, 386; (b) S. Bock, O. A. Al-Owaedi, S. G. Eaves, D. C. Milan, M. Lemmer, B. W. Skelton, H. M. Osorio, R. J. Nichols, S. J. Higgins, P. Cea, N. J. Long, T. Albrecht, S. Martín, C. J. Lambert and P. J. Low, Chem.-Eur. J., 2017, 23, 2133; (c) B. S. Kim, J. M. Beebe, C. Olivier, S. Rigaut, D. Touchard, J. G. Kushmerick, X.-Y. Zhu and C. D. Frisbie, J. Phys. Chem. C, 2007, 111, 7521; (d) L. Luo, A. Benameur, P. Brignou, S. H. Choi, S. Rigaut and C. D. Frisbie, J. Phys. Chem. C, 2011, 115, 19955; (e) N. A. Wasio, R. C. Quardokus, R. P. Forrest, S. A. Corcelli, Y. Lu, C. S. Lent, F. Justaud, C. Lapinte and S. A. Kandel, J. Phys. Chem. C, 2012, 116, 25486; (f) E. Wuttke, F. Pevny, Y.-M. Hervault, L. Norel, M. Drescher, R. F. Winter and S. Rigaut, Inorg. Chem., 2012, 51, 1902; $(g)$ F. Lissel, T. Fox, O. Blacque, W. Polit, R. F. Winter, K. Venkatesan and H. Berke, J. Am. Chem. Soc., 2013, 135, 3826.

19 (a) A. B. Ricks, G. C. Solomon, M. T. Colvin, A. M. Scott, K. Chen, M. A. Ratner and M. R. Wasielewski, J. Am. Chem. Soc., 2010, 132, 15427; (b) P. J. Mosher, G. P. A. Yap and R. J. Crutchley, Inorg. Chem., 2001, 40, 1189; (c) R. H. Laye, S. M. Couchman and M. D. Ward, Inorg. Chem., 2001, 40, 
4089; (d) M. D. Todd, A. Nitzan and M. A. Ratner, J. Phys. Chem., 1993, 97, 29.

20 M. B. Robin and P. Day, Adv. Inorg. Chem. Radiochem., 1967, 10, 247.

21 (a) S. Dammers, T. P. Zimmermann, S. Walleck, A. Stammler, H. Bögge, E. Bill and T. Glaser, Inorg. Chem., 2017, 56, 1779; (b) S. Ghumaan and G. K. Lahiri, J. Chem. Sci., 2006, 118, 537; (c) Y.-W. Zhong, Z.-L. Gong, J.-Y. Shao and J. Yao, Coord. Chem. Rev., 2016, 312, 22; (d) H.-N. Nie, J.-Y. Shao, C.-J. Yao and Y.-W. Zhong, Chem. Commun., 2014, 50, 10082. 22 (a) M. D. Ward, Chem. Soc. Rev., 1995, 24, 121; (b) J. A. McCleverty and M. D. Ward, Acc. Chem. Res., 1998, 31, 842; (c) D. Astruc, Acc. Chem. Res., 1997, 30, 383.

23 (a) D. E. Richardson and H. Taube, J. Am. Chem. Soc., 1983, 105, 40; (b) L. T. Zhang, J. Ko and M. J. Ondrechen, J. Am. Chem. Soc., 1987, 109, 1666; (c) S. D. Glover, J. C. Goeltz, B. J. Lear and C. P. Kubiak, Coord. Chem. Rev., 2010, 254, 331; (d) S. D. Glover, J. C. Goeltz, B. J. Lear and C. P. Kubiak, Eur. J. Inorg. Chem., 2009, 585; (e) C. P. Kubiak, Inorg. Chem., 2013, 52, 5663; $(f)$ B. J. Lear, S. D. Glover, J. C. Salsman, C. H. Londergan and C. P. Kubiak, J. Am. Chem. Soc., 2007, 129, 12772.

24 (a) R. J. Crutchley, Adv. Inorg. Chem., 1994, 41, 273; (b) C. E. B. Evans, M. L. Naklicki, A. R. Rezvani, C. A. White, V. V. Kondratiev and R. J. Crutchley, J. Am. Chem. Soc., 1998, 120, 13096; (c) M. Al-Noaimi, G. P. A. Yap and R. J. Crutchley, Inorg. Chem., 2004, 43, 1770; (d) R. J. Crutchley, Angew. Chem., Int. Ed., 2005, 44, 6452; (e) D. M. D'Alessandro and F. R. Keene, Dalton Trans., 2004, 3950; ( $f$ ) R. F. Winter, Organometallics, 2014, 33, 4517; $(g)$ S. Santi, A. Bisello, R. Cardena and A. Donoli, Dalton Trans., 2015, 44, 5234.

25 (a) K. D. Demadis, D. C. Hartshorn and T. J. Meyer, Chem. Rev., 2001, 101, 2655; (b) M. A. Fox, B. L. Guennic, R. L. Roberts, D. A. Brue, D. S. Yufit, J. A. K. Howard, G. Manca, J. Halet, F. Hartl and P. J. Low, J. Am. Chem. Soc., 2011, 133, 18433; (c) F. Ding, H. Wang, Q. Wu, T. V. Voorhis, S. Chen and J. P. Konopelski, J. Phys. Chem. A, 2010, 114, 6039; (d) E. Göransson, R. Emanuelsson, K. Jorner, T. F. Markle, L. Hammarström and H. Ottosson, Chem. Sci., 2013, 4, 3522; (e) D. M. D'Alessandro and F. R. Keene, Chem. Soc. Rev., 2006, 35, 424.

26 (a) N. S. Hush, Prog. Inorg. Chem., 1967, 8, 391; (b) C. Creutz, M. D. Newton and N. Sutin, J. Photochem. Photobiol., A, 1994, 82, 47.

27 D. H. Oh, M. Sano and S. G. Boxer, J. Am. Chem. Soc., 1991, 113, 6880.

28 (a) N. S. Hush, Coord. Chem. Rev., 1985, 64, 135; (b) N. A. Lewis, R. R. McNeer and D. V. Taveras, Inorg. Chim. Acta, 1994, 225, 89.

29 (a) J. T. Hupp, Comprehensive Coordination Chemistry II, ed. J. A. McCleverty and T. J. Meyer, Elsevier Science, Amsterdam, 2003, p. 709; (b) P. Chen and T. J. Meyer, Chem. Rev., 1998, 98, 1439.
30 (a) J. C. Salsman and C. P. Kubiak, J. Am. Chem. Soc., 2005, 127, 2382; (b) C. H. Londergan and C. P. Kubiak, Chem.Eur. J., 2003, 9, 5962; (c) C. H. Londergan and C. P. Kubiak, J. Phys. Chem. A, 2003, 107, 9301; (d) C. H. Londergan, J. C. Salsman, S. Ronco, L. M. Dolkas and C. P. Kubiak, J. Am. Chem. Soc., 2002, 124, 6236; (e) T. Ito, T. Hamaguchi, H. Nagino, T. Yamaguchi, J. Washington and C. P. Kubiak, Science, 1997, 277, 660; (f) T. Ito, T. Hamaguchi, H. Nagino, T. Yamaguchi, H. Kido, I. S. Zaverine, T. Richmond, J. Washington and C. P. Kubiak, J. Am. Chem. Soc., 1999, 121, 4625.

31 (a) W. Kaim and B. Sarkar, Coord. Chem. Rev., 2013, 257, 1650; (b) S. Patra, B. Sarkar, S. M. Mobin, W. Kaim and G. K. Lahiri, Inorg. Chem., 2003, 42, 6469.

32 P. Mondal, F. Ehret, M. Bubrin, A. Das, S. M. Mobin, W. Kaim and G. K. Lahiri, Inorg. Chem., 2013, 52, 8467.

33 (a) W. Kaim and V. Kasack, Inorg. Chem., 1990, 29, 4696; (b) T. Scheiring, W. Kaim, J. A. Olabe, A. R. Parise and J. Fiedler, Inorg. Chim. Acta, 2000, 125, 300.

34 C. G. Atwood and W. E. Geiger, J. Am. Chem. Soc., 2000, 122, 5477.

35 (a) M. Chatterjee, P. Mondal, K. Beyer, A. Paretzki, W. Kaim and G. K. Lahiri, Dalton Trans., 2017, 46, 5091; (b) M. A. Ansari, A. Mandal, K. Beyer, A. Paretzki, B. Schwederski, W. Kaim and G. K. Lahiri, Dalton Trans., 2017, 46, 15589; (c) P. Mondal, M. Chatterjee, A. Paretzki, K. Beyer, W. Kaim and G. K. Lahiri, Inorg. Chem., 2016, 55, 3105; (d) M. Moscherosch, E. WaldhIr, H. Binder, W. Kaim and J. Fiedler, Inorg. Chem., 1995, 34, 4326; (e) S. Ghumaan, S. Mukherjee, S. Kar, D. Roy, S. M. Mobin, R. B. Sunoj and G. K. Lahiri, Eur. J. Inorg. Chem., 2006, 4426. 36 (a) T. Kundu, D. Schweinfurth, B. Sarkar, T. K. Mondal, J. Fiedler, S. M. Mobin, V. G. Puranik, W. Kaim and G. K. Lahiri, Dalton Trans., 2012, 41, 13429; (b) T. Kundu, B. Sarkar, T. K. Mondal, J. Fiedler, S. M. Mobin, W. Kaim and G. K. Lahiri, Inorg. Chem., 2010, 49, 6565; (c) M. Koley, B. Sarkar, S. Ghumaan, E. Bulak, J. Fiedler, W. Kaim and G. K. Lahiri, Inorg. Chem., 2007, 46, 3736; (d) S. Ghumaan, B. Sarkar, N. Chanda, M. Sieger, J. Fiedler, W. Kaim and G. K. Lahiri, Inorg. Chem., 2006, 45, 7955; (e) N. Chanda, B. Sarkar, S. Kar, J. Fiedler, W. Kaim and G. K. Lahiri, Inorg. Chem., 2004, 43, 5128; ( $f$ ) N. Chanda, B. Sarkar, J. Fiedler, W. Kaim and G. K. Lahiri, Dalton Trans., 2003, 3550; $(g)$ N. Chanda, R. H. Laye, S. Chakraborty, R. L. Paul, J. C. Jeffery, M. D. Ward and G. K. Lahiri, J. Chem. Soc., Dalton Trans., 2002, 3496.

37 (a) R. Hage, J. G. Haasnoot, H. A. Nieuwenhuis, J. Reedijk, D. J. A. D. Ridder and J. G. Vos, J. Am. Chem. Soc., 1990, 112, 9245; (b) T. Ito, N. Imai, T. Yamaguchi, T. Hamaguchi, C. H. Londergan and C. P. Kubiak, Angew. Chem., Int. Ed., 2004, 43, 1376; (c) J. C. Salsman, S. Ronco, C. H. Londergan and C. P. Kubiak, Inorg. Chem., 2006, 45, 547; (d) C. H. Londergan, J. C. Salsman, B. J. Lear and C. P. Kubiak, Chem. Phys., 2006, 324, 57; (e) P. V. Bernhardt, F. Bozoglián, M. Font-Bardía, M. Martínez, 
A. P. Meacham, B. Sienra and X. Solans, Eur. J. Inorg. Chem., 2007, 5270; (f) S. D. J. McKinnon, B. O. Patrick, A. B. P. Lever and R. G. Hicks, Inorg. Chem., 2013, 52, 8053; $(g)$ D. M. Dattelbaum, C. M. Hartshorn and T. J. Meyer, J. Am. Chem. Soc., 2002, 124, 4938; (h) M. Dürr, J. Klein, A. Kahnt, S. Becker, R. Puchta, B. Sarkar and I. Ivanović-Burmazović, Inorg. Chem., 2017, 56, 14912; (i) A. Das, T. M. Scherer, A. D. Chowdhury, S. M. Mobin, W. Kaim and G. K. Lahiri, Inorg. Chem., 2012, 51, 1675.

38 (a) H. Agarwala, T. Scherer, S. Maji, T. K. Mondal, S. M. Mobin, J. Fiedler, F. A. Urbanos, R. Jiménez-Aparicio, W. Kaim and G. K. Lahiri, Chem.-Eur. J., 2012, 18, 5667; (b) S. Kar, B. Sarkar, S. Ghumaan, D. Roy, F. A. Urbanos, J. Fiedler, R. B. Sunoj, R. Jiménez-Aparicio, W. Kaim and G. K. Lahiri, Inorg. Chem., 2005, 44, 8715; (c) Y. Hoshino, S. Higuchi, J. Fiedlar, C. Y. Su, A. Knödler, B. Schwederski, B. Sarkar, H. Hartmann and W. Kaim, Angew. Chem., Int. Ed., 2003, 42, 674.

39 T. D. Glover, B. J. Lear, J. C. Salsman, C. H. Londergan and C. P. Kubiak, Philos. Trans. R. Soc., A, 2008, 366, 177.

40 S. Patra, B. Sarkar, S. Ghumaan, J. Fiedler, W. Kaim and G. K. Lahiri, Inorg. Chem., 2004, 43, 6108.

41 S. Chellamma and M. Lieberman, Inorg. Chem., 2001, 40, 3177.

42 (a) M. D. Ward, Inorg. Chem., 1996, 35, 1712; (b) B. D. Yeomans, L. S. Kelso, P. A. Tregloan and F. R. Keene, Eur. J. Inorg. Chem., 2009, 585; (c) M. D. Ward and J. A. McCleverty, J. Chem. Soc., Dalton Trans., 2002, 275; (d) S. Patra, B. Sarkar, S. Ghumaan, J. Fiedler, W. Kaim and G. K. Lahiri, Dalton Trans., 2004, 754.

43 A. Das, T. Scherer, S. Maji, T. K. Mondal, S. M. Mobin, F. A. Urbanos, R. Jiménez-Aparicio, W. Kaim and G. K. Lahiri, Inorg. Chem., 2011, 50, 7040.

44 (a) J.-P. Sutter, D. M. Grove, M. Beley, J.-P. Collin, N. Veldman, A. L. Spek, J.-P. Sauvage and G. van Koten, Angew. Chem., Int. Ed., 1994, 33, 1282; (b) J. P. Collin, P. Laine, J. P. Launay, J. P. Sauvage and A. Sour, J. Chem. Soc., Chem. Commun., 1993, 434.

45 (a) S. Chakraborty, R. H. Laye, P. Munshi, R. L. Paul, M. D. Ward and G. K. Lahiri, J. Chem. Soc., Dalton Trans., 2002, 2348; (b) Y. Halpin, D. Dini, H. M. Y. Ahmed, L. Cassidy, W. R. Browne and J. G. Vos, Inorg. Chem., 2010, 49, 2799; (c) H. M. Y. Ahmed, N. Coburn, D. Dini, J. J. D. Jong, C. de Villani, W. R. Browne and J. G. Vos, Inorg. Chem., 2011, 50, 5861; (d) M. Heilmann, S. Frantz, W. Kaim, J. Fiedler and C. Duboc, Inorg. Chim. Acta, 2006, 359, 821-829; (e) A. das, T. M. Scherer, S. M. Mobin, W. Kaim and G. K. Lahiri, Chem.-Eur. J., 2012, 18, 11007; $(f)$ F. Scandola, R. Argazzi, C. A. Bignozzi, C. Chiorboli, M. T. Indelli and M. A. Rampi, Coord. Chem. Rev., 1993, 125, 283; $(g)$ H. Vahrenkamp, A. Geiss and G. N. Richardson, J. Chem. Soc., Dalton Trans., 1997, 3643; (h) N. Zhu and H. Vahrenkamp, Chem. Ber., 1997, 130, 1241.
46 A. Das, T. Kundu, S. M. Mobin, J. L. Priego, R. JiménezAparicio and G. K. Lahiri, Dalton Trans., 2013, 42, 13733.

47 (a) C. Remenyi and M. Kaupp, J. Am. Chem. Soc., 2005, 127, 11399; (b) S. Roy, B. Sarkar, D. Bubrin, M. Niemeyer, S. Záliš, G. K. Lahiri and W. Kaim, J. Am. Chem. Soc., 2008, 130, 15230; (c) A. Das, P. Ghosh, S. Plebst, B. Schwederski, S. M. Mobin, W. Kaim and G. K. Lahiri, Inorg. Chem., 2015, 54, 3376.

48 (a) P. Ghosh, S. Panda, S. Banerjee and G. K. Lahiri, Inorg. Chem., 2017, 56, 10735; (b) S. Panda, A. Mandal, P. Ghosh and G. K. Lahiri, Inorg. Chem., 2017, 56, 14900; (c) P. Ghosh, S. Banerjee and G. K. Lahiri, Inorg. Chem., 2017, 55, 12832; (d) A. S. Hazari, A. Paretzki, J. Fiedler, S. Zalis, W. Kaim and G. K. Lahiri, Dalton Trans., 2016, 45, 18241; (e) M. A. Ansari, A. Mandal, A. Paretzki, K. Beyer, J. Fiedler, W. Kaim and G. K. Lahiri, Inorg. Chem., 2016, 55, 5655; (f) P. Mondal, A. Das and G. K. Lahiri, Inorg. Chem., 2016, 55, 1208; (g) P. Ghosh and G. K. Lahiri, Dalton Trans., 2016, 45, 5240; (h) A. Mandal, B. Schwederski, J. Fiedler, W. Kaim and G. K. Lahiri, Inorg. Chem., 2015, 54, 8126; (i) P. Mondal, R. Ray, A. Das and G. K. Lahiri, Inorg. Chem., 2015, 54, 3012; (j) P. Ghosh, R. Ray, A. Das and G. K. Lahiri, Inorg. Chem., 2014, 53, 10695; (k) P. Mondal, S. Plebst, R. Ray, S. M. Mobin, W. Kaim and G. K. Lahiri, Inorg. Chem., 2014, 53, 9348; (l) H. Masui, A. L. Freda, M. C. Zerner and A. B. P. Lever, Inorg. Chem., 2000, 39, 141; $(m)$ N. Roy, S. Sproules, T. Weyhermueller and K. Wieghardt, Inorg. Chem., 2009, 39, 141; (n) B. Sarkar, S. Patra, J. Fiedler, R. B. Sunoj, D. Janardanan, S. M. Mobin, M. Niemeyer, G. K. Lahiri and W. Kaim, Angew. Chem., Int. Ed., 2005, 44, 5655; (o) B. Sarkar, S. Patra, J. Fiedler, R. B. Sunoj, D. Janardanan, G. K. Lahiri and W. Kaim, J. Am. Chem. Soc., 2008, 130, 3532.

49 (a) J. S. Miller and K. S. Min, Angew. Chem., Int. Ed., 2009, 48, 262; (b) S. Ghumaan, B. Sarkar, S. Patra, J. V. Slageren, J. Fiedler, W. Kaim and G. K. Lahiri, Inorg. Chem., 2005, 44, 3210.

50 A. Mandal, A. Grupp, B. Schwederski, W. Kaim and G. K. Lahiri, Inorg. Chem., 2015, 54, 10049.

51 (a) T. Kundu, B. Sarkar, T. K. Mondal, S. M. Mobin, F. A. Urbanos, J. Fiedler, R. Jiménez-Aparicio, W. Kaim and G. K. Lahiri, Inorg. Chem., 2011, 50, 4753; (b) A. K. Das, B. Sarkar, J. Fiedler, S. Zális, I. Hartenbach, S. Strobel, G. K. Lahiri and W. Kaim, J. Am. Chem. Soc., 2009, 131, 8895. 52 A. S. Hazari, A. Mandal, K. Beyer, A. Paretzki, W. Kaim and G. K. Lahiri, Inorg. Chem., 2017, 56, 2992.

53 D. Kumbhakar, B. Sarkar, S. Maji, S. M. Mobin, J. Fiedler, F. A. Urbanos, R. Jiménez-Aparicio, W. kaim and G. K. Lahiri, J. Am. Chem. Soc., 2008, 130, 17575.

54 (a) A. Klein, O. Lavastre and J. Fiedler, Organometallics, 2006, 25, 635; (b) G.-L. Xu, G. Zou, Y.-H. Ni, M. C. DeRosa, R. J. Crutchley and T. Ren, J. Am. Chem. Soc., 2003, 125, 10057; (c) J.-H. Tang, J.-H. Shao, Y.-Q. He, Si.-H. Wu, J. Yao and Y.-W. Zhong, Chem.-Eur. 
J., 2016, 22, 10341; (d) W. P. Forrest, Z. Cao, K. M. Hassell, B. M. Prentice, P. E. Fanwick and T. Ren, Inorg. Chem., 2012, 51, 3261.

55 (a) D. Chong, X. Wan and J. Zhang, J. Mater. Chem. C, 2017, 5, 6442; (b) J. A. Christie, R. P. Forrest, S. A. Corcelli, N. A. Wasio, R. C. Quardok, R. Brown, S. A. Kandel, Y. Lu, C. S. Lent and K. W. Henderson, Angew. Chem., Int. Ed., 2015, 54, 15448; (c) T. Matsumoto, G. N. Newton, T. Shiga, S. Hayami, Y. Matsui, H. Okamoto, R. Kumai, Y. Murakami and H. Oshio, Nat. Commun., 2014, 5, 3865.
56 G. LeClair and Z. Y. Wand, J. Solid State Electrochem., 2009, 13, 365 .

57 (a) R. Murase, C. F. Long and D. M. D'Alessandro, Inorg. Chem., 2017, 56, 14373; (b) L. Sun, M. G. Campbell and M. Dincă, Angew. Chem., Int. Ed., 2016, 55, 3566.

58 (a) P. Zhang, X. Hou, L. Liu, J. Mi and M. Dong, J. Phys. Chem. C, 2015, 119, 28028; (b) F. Bozoglian, S. Romain, M. Z. Ertem, T. K. Todorova, C. Sens, J. Mola, M. Rodriguez, I. Romero, J. B.-. Buchholz, X. Fontrodona, C. J. Cramer, L. Gagliardi and A. Llobet, J. Am. Chem. Soc., 2009, 131, 15176. 